\title{
A Meta-Analysis of the Antecedents and Consequences of Pay Level Satisfaction
}

\author{
Margaret L. Williams, Michael A. McDaniel, and Nhung T. Nguyen \\ Virginia Commonwealth University
}

\begin{abstract}
This study reports results from a meta-analysis of 28 correlates of pay level satisfaction involving 240 samples from 203 studies conducted over the past 35 years. Results are presented in 4 categories: primary determinants, antecedents, correlates, and outcomes of pay satisfaction. The authors controlled for pay in examining relations between correlates and pay level satisfaction, as suggested by theory and when primary studies were available to do so. The authors found support for many of the relations suggested by a theoretical model and also note some limitations in the research that has tested this model. The authors recommend changes and additions to the model and suggest additional primary research in specific areas.
\end{abstract}

Keywords: compensation, pay level, satisfaction, meta-analysis

Although there is no doubt that employees' satisfaction with their pay has always been of primary concern to employees as well as employers, it was in the 1960 s that researchers first systematically studied factors affecting employee pay satisfaction. The motivations for wanting to understand pay satisfaction are varied. First, employee compensation is one of the largest costs of doing business, representing $57 \%$ of the total value of goods and services produced in the United States in 2002 (U.S. Bureau of Economic Analysis, 2003). Second, as noted by Dreher, Ash, and Bretz (1988), the expectation is that the relation between compensation and work outcomes is mediated by attitudinal reactions to pay. Thus, pay satisfaction may be viewed as a necessary but not a sufficient condition for organizations to achieve the goals of their compensation systems, such as employee retention and motivation. Third, if employers understand the antecedents of pay satisfaction, they can influence employees' levels of pay satisfaction. This is of particular interest because employers can likely control more antecedents of pay satisfaction (in terms of strategic decisions about their compensation systems) than they can other sources of job satisfaction, such as satisfaction with coworkers or supervisors. The purpose of this study is to summarize the empirical literature on pay satisfaction, review progress in testing the dominant theoretical models, and highlight avenues for future research.

Pay satisfaction can be defined as the "amount of overall positive or negative affect (or feelings) that individuals have toward their pay" (Miceli \& Lane, 1991, p. 246). Conventionally, the word

Margaret L. Williams, Michael A. McDaniel, and Nhung T. Nguyen, School of Business, Virginia Commonwealth University.

Nhung T. Nguyen is now at the College of Business and Economics, Towson University.

We acknowledge Jianmin Li, Julie McManus, and the staff of the Interlibrary Loan Office at Virginia Commonwealth University for their assistance in conducting this study.

Correspondence concerning this article should be addressed to Margaret L. Williams, School of Business, Virginia Commonwealth University, P.O. Box 844000, Richmond, VA 23284-4000. E-mail: mlwillia@vcu.edu pay refers to all forms of compensation, such as direct, cash payments (e.g., salary); indirect, noncash payments (e.g., benefits); and the amount of pay raises and the process by which the compensation system is administered. Several authors, the most notable H. G. Heneman and Schwab (1985), have suggested that this broad definition of pay satisfaction should be replaced by a multidimensional conceptualization of pay satisfaction (e.g., H. G. Heneman, 1985; Judge, 1993; Scarpello, Huber, \& Vandenberg, 1988). This suggests that the research related to various dimensions of pay satisfaction should be examined and reviewed separately. In this study, we focus on the largest group of studiesthose that address pay level satisfaction, defined as "an individual's satisfaction with his or her base pay" (Miceli \& Lane, 1991, p. 245).

\section{The Current Study}

Despite the fact that researchers have studied pay level satisfaction and its correlates for more than 40 years, no study has provided a comprehensive summary of this body of research. Several narrative reviews of the pay satisfaction literature exist (e.g., H. G. Heneman, 1985; H. G. Heneman \& Judge, 2000; H. G Heneman \& Schwab, 1979); however, each represents a snapshot of the research conducted during a specific time frame rather than a comprehensive review. In addition, limited quantitative summary data are available. Kinicki, McKee-Ryan, Schriesheim, and Carson (2002) conducted a meta-analysis of the Job Descriptive Index (JDI; Smith, Kendall, \& Hulin, 1969), including the pay level satisfaction facet. Although Kinicki et al. (2002) provided a thorough review of the JDI, their results are of limited use in summarizing the pay level satisfaction literature for three reasons: (a) They limited their review to studies using only one measure of pay satisfaction (the JDI), (b) they included studies from only five journals, and (c) because their study was not based on a theoretical model of pay level satisfaction, they excluded many correlates of pay level satisfaction (they examined only 8 of the 28 correlates included in this study). Our review allows us to use the vast 
amount of accumulated research to update theoretical models of the antecedents and consequences of pay level satisfaction.

In addition to this general objective, we advance the study of pay level satisfaction in three ways. First, although researchers have noted the importance of controlling for actual pay when examining relations among antecedents of pay level satisfaction, not all primary studies have done so. When possible, we examine relations controlling for pay level. Second, we identify underresearched areas in which additional primary research would be useful. Finally, as noted by H. G. Heneman (1985), the distinction among the dimensions of pay satisfaction was not recognized in empirical research until the late 1970s or early 1980s. Thus, a proportion of the empirical studies of pay satisfaction used measures that subsequently have been judged to assess an overall pay satisfaction construct (i.e., general pay satisfaction). Because we wish to understand the impact of this practice on the existing body of research, we include these studies in the meta-analysis and examine the impact of the type of pay measure (i.e., pay level vs. general pay satisfaction) on relations between pay level satisfaction and its correlates.

In addition to the general contributions described above, our analysis allows us to address five specific research questions. First, do pay discrepancies (the judgments that employees make about how their actual pay compares with the pay they should receive) mediate the relations between pay level satisfaction and other antecedents? Second, are pay discrepancies related to pay level satisfaction in the manner suggested by equity theory or discrepancy theory? Third, do accumulated research results support the paradox of the contented female worker (Crosby, 1982), the finding that although women tend to make less income than men, they are not less satisfied with their pay? Fourth, does such a paradox exist for another demographic group, that is, historically underpaid racial minorities? Fifth, do constructs described by job characteristics theories (e.g., autonomy and task feedback) affect pay level satisfaction? We now turn to a discussion of the theoretical relations underlying the study of pay satisfaction.

\section{Theoretical Background}

Two theories of the causes of pay level satisfaction have guided research over the past 35 years: equity theory (Adams, 1965) and discrepancy theory (Lawler, 1971, 1981). Figure 1 shows a model (based on the work of H. G. Heneman, 1985; Lawler, 1971; and Miceli \& Lane, 1991) that combines both theories of the causes of pay level satisfaction. In this model, we include primary determinants (i.e., the difference between deserved and actual pay), antecedents (i.e., perceived inputs and outcomes of others), correlates (i.e., justice constructs), and consequences (i.e., absenteeism and turnover) of pay level satisfaction. We use this model to guide our meta-analysis and to frame and organize our findings.

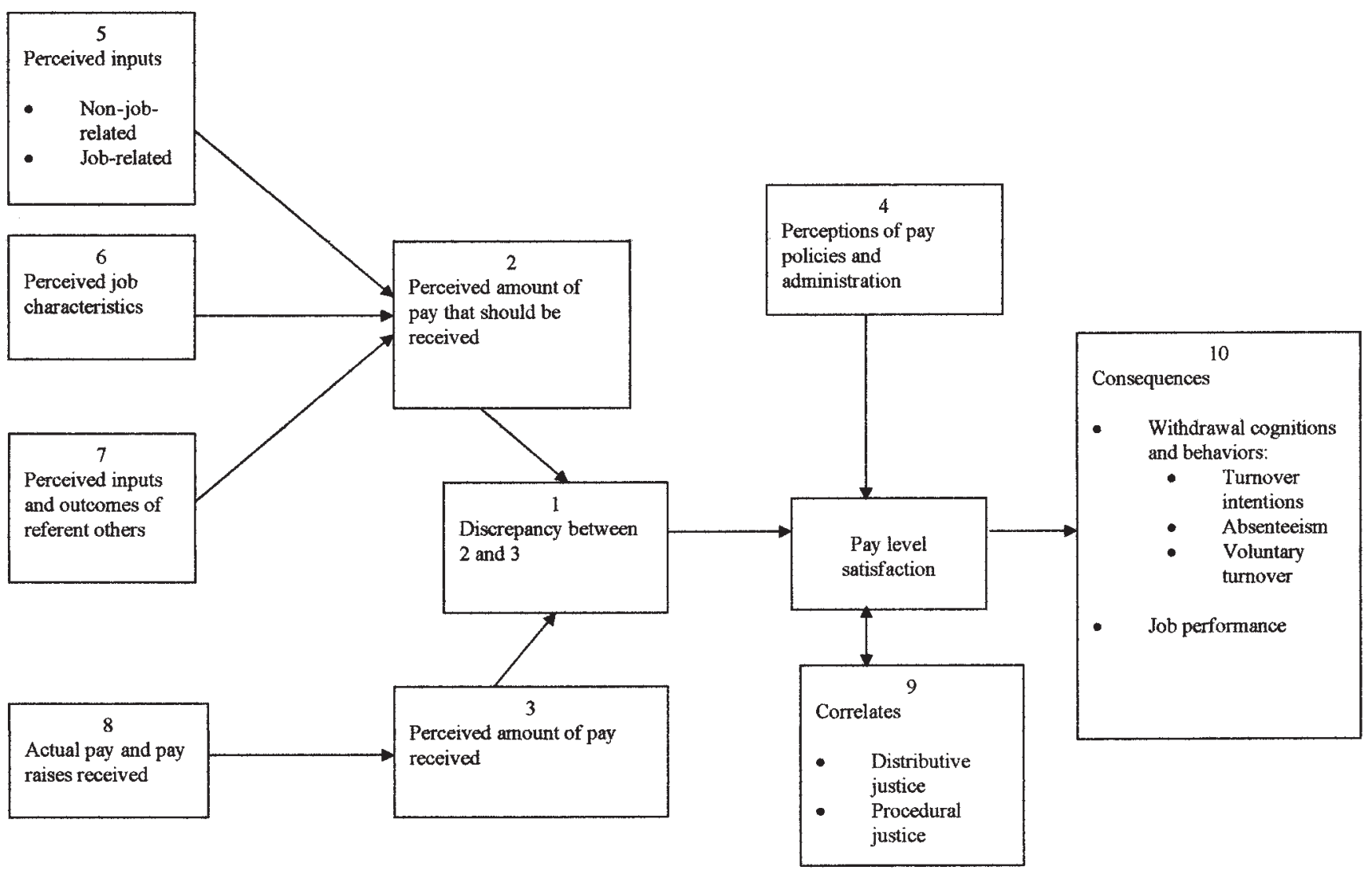

Figure 1. Current model of the antecedents and consequences of pay level satisfaction (based on H. G. Heneman, 1985; Lawler, 1971; and Miceli \& Lane, 1991). 


\section{Primary Determinants}

Discrepancy between perceived amount of pay that should be received and perceived amount of pay received (Box 1). The model indicates that the primary determinant of pay level satisfaction is the discrepancy between the pay that should be received (Box 2) and the amount of pay actually received (Box 3). This depiction is based on both discrepancy and equity theories. There are several areas of agreement between the two theories. First, both theories suggest that the perceived amount of pay that should be received and the perceived amount of pay received are the primary determinants of pay satisfaction. Second, both theories are in agreement that when these two determinants are equal, employees will be satisfied with their pay. Third, both theories postulate that when the perceived amount of pay deserved is greater than the amount received (Box $2>$ Box 3 in Figure 1), employees will be dissatisfied with their pay. Although, in its original form (Lawler, 1971), discrepancy theory was consistent with equity theory in its prediction that feelings of guilt and thus dissatisfaction would result from overpayment (Box $2<$ Box 3 in Figure 1), more recent theorizing has called this relation into question. Miceli and Lane (1991) claimed that overpayment may lead to satisfaction instead of dissatisfaction, and Scarpello (1988) advanced the theory that overreward may cause people to be satisfied but to view the outcome as unfair. We examine whether overreward is associated with lower or higher levels of pay satisfaction.

Perceptions of pay policies and administration (Box 4). Box 4 shows that perceptions of pay policies and administration (i.e., perceptions of how the pay system operates) are expected to relate to pay level satisfaction (Dyer \& Theriault, 1976). Despite the fact that these antecedents have been incorporated into models of pay level satisfaction for nearly 30 years, only employees' perception of the performance-reward contingency operating in the organization had enough primary research studies to be included in our meta-analysis. We expect a positive relation between performancereward contingency and pay level satisfaction. Employees who perceive that performance is instrumental to the attainment of a valued outcome, such as a pay raise, should be more satisfied with their pay outcomes than those who do not perceive this connection (R. L. Heneman, Greenberger, \& Strasser, 1988). An additional argument supporting a positive relation between performancereward contingency and pay level satisfaction is that those who are satisfied with their pay are likely to believe that their pay is based on their level of performance or merit.

\section{Antecedents}

The remaining categories in the pay level satisfaction antecedent model (Boxes 5-8) are viewed as antecedents of the primary determinants (amount of pay that should be received and amount of pay received). These categories (shown in Figure 1) are perceived inputs, perceived job characteristics, perceived inputs and outcomes of referent others, and actual pay and pay raises received.

Perceived inputs (Box 5). There are two categories of perceived inputs shown in Box 5: non-job-related and job related (Pelled, Eisenhardt, \& Xin, 1999). Miceli and Lane (1991) argued that non-job-related inputs, such as age, marital status, gender, and ethnicity, may serve as determinants of the perceived amount of pay that should be received. Thus, for example, older or married employees may believe that they deserve more pay than younger or unmarried employees. According to Lawler (1971), this suggests a negative relation between these factors and pay level satisfaction. Two of these characteristics have received a great deal of theoretical and empirical attention. First, the gender wage gap continues to persist within North America, and the presence of this gap suggests that women should be less satisfied than men with their pay. However, this expected difference in pay satisfaction does not exist, leading researchers to try to explain the paradox of the contented female worker (Crosby, 1982; Major \& Konar, 1984). This meta-analysis provides the best estimate to date of this paradox as observed for the past 3 decades. Second, few studies have examined the relation between ethnicity and pay level satisfaction. There is a wage gap between majority group (White) earnings and the earnings of minority groups, yet there is no evidence to support a paradox similar to that found for female employees. On the basis of equity theory, it is likely that differences in pay satisfaction between Whites and non-Whites are due to factors in addition to actual pay level (e.g., comparisons with relevant others in terms of inputs as well as outcomes and whether referent others belong to the same ethnic group or either higher or lower paid groups); however, we expect that satisfaction levels are likely to be associated with existing, persistent pay differences as well. Thus, we expect White employees to be more satisfied with their pay level than ethnic minorities.

Job-related inputs in Box 5 include education, experience, job level, job tenure, and organizational tenure. According to early theorists, the higher the level of these job inputs is, the higher is the perceived amount of pay that should be received. Lawler (1971) and others (e.g., Schwab \& Wallace, 1974) noted that factors that raise employees' pay expectations are likely to decrease pay level satisfaction, "other things being equal" (Lawler, 1971, p. 217). To examine this, it is important that one control for actual pay level. Thus, we expect weak, although possibly positive, relations between these job-related inputs and pay level satisfaction when we do not control for pay and weak negative relations when we control for pay.

Perceived job characteristics (Box 6). Box 6 indicates that perceived job characteristics predict the perceived amount of pay that should be received. The job characteristics that have appeared most frequently in the pay level satisfaction literature are those from the job characteristics model (Hackman \& Oldham, 1974): autonomy, skill variety, task feedback, task identity, task significance, and their aggregate-job scope. Several arguments support a positive relation between job characteristics and pay level satisfaction. Lawler (1971) suggested that nonmonetary outcomes (e.g., autonomy) are likely to be positively related to pay level satisfaction because they may help satisfy some of the same individual needs that pay does. More recently, Campion and Berger (1990) supported Lawler's point by arguing that both job design and compensation can be viewed as rewards. Further, the logic behind the job characteristics model is that actions that enhance the core psychological states should increase satisfaction; thus, we might expect positive relations between the core job dimensions and pay level satisfaction. Finally, individuals who work in enriched jobs (i.e., those that require higher levels of skill and responsibility for their completion) may, in fact, be paid more than those who work in jobs with lower levels of enrichment. Empirical results support 
arguments for a positive relation between perceived job characteristics and pay level satisfaction. Kinicki et al. (2002) found population correlations (corrected for unreliability) between core job characteristics and the pay satisfaction facet of the JDI ranging from .14 to .23 .

An alternative argument seems worth noting, however. Just as job inputs are thought to be negatively related to pay level satisfaction because of their role in raising pay expectations, employees who must invest more mental energy into their enriched jobs may expect higher levels of pay to compensate for their greater levels of responsibility (Locke, Sirota, \& Wolfson, 1976; O'Reilly \& Caldwell, 1979). This is the perspective represented in Figure 1, because job characteristics are shown as predictors of pay that should be received. This representation suggests negative relations between job characteristics and pay level satisfaction if the greater requirements of enriched jobs are not associated with higher pay in return. On the basis of these arguments, we examine the relations between job characteristics and pay level satisfaction controlling for pay.

Perceived inputs and outcomes of referent others (Box 7). Perceived inputs and outcomes of referent others are viewed as antecedents of the perceived amount of pay that should be received. In general, factors that increase the perceived amount of pay that should be received are negatively related to pay level satisfaction (Rice, Phillips, \& McFarlin, 1990). In empirical research, however, these constructs have usually been examined as direct antecedents of pay level satisfaction, and the measurement approach typically used yields positive relations with pay level satisfaction. In most cases, researchers assess perceived inputs and outcomes of referent others by asking a question such as, "Compared with those working in similar jobs in other organizations [or another basis of comparison], your pay is much worse, somewhat worse," and so forth, with a high score representing a positive comparison (i.e., much better). Studies have typically shown these measures to be positively related to pay level satisfaction. In addition, pay level satisfaction research has suggested that employees use a variety of comparisons (Goodman, 1974; Lawler, 1971; Summers \& DeNisi, 1990) to determine their degree of pay level satisfaction. Two relevant groupings of referents are those within the same organization (i.e., internal comparisons-related to internal equity; Milkovich \& Newman, 2005) and those doing similar work for other organizations (i.e., external comparisonsrelated to external equity or competitiveness; Milkovich \& Newman, 2005). In addition, employees may use other inputs, both job related and non-job-related (as described earlier), for comparisons. Because fewer studies have examined this type of comparison, we group these referents into a third category, called general comparisons. Both internal and external comparisons refer to individuals who are most salient to employees when they evaluate their pay equity; therefore, we expect both internal and external comparisons to be more strongly related to pay level satisfaction than are general comparisons.

Actual pay and pay raises received (Box 8). As noted by H. G. Heneman (1985), the relation between actual pay (Box 8) and pay level satisfaction is one of the most robust (yet hardly surprising) findings of past research. What has been surprising to many researchers is how low this relation appears to be; typically, $r=$ .15 (H. G. Heneman \& Judge, 2000). We expect to find a positive relation between pay amounts and pay level satisfaction, and, because we correct for unreliability in our meta-analysis, we expect the population correlation between pay and pay level satisfaction to exceed .15. The actual level of pay raises (also included in Box 8) is not found in Lawler's (1971) discrepancy model of pay level satisfaction. Because pay raises affect the perceived amount of pay received, we expect that pay raise percentage will be positively related to pay level satisfaction.

Not included in our pay level satisfaction antecedent model. Both Lawler (1971) and H. G. Heneman (1985) included an additional antecedent of perceived amount of pay received in their model: perceived pay of referent others. Lawler (1971) argued that

present wage rate is the key influence on a person's perception of what his pay is, but his perception is also shown to be influenced by $\ldots$ his perception of what his referent others receive. . . The higher the pay of his referent others, the lower his pay will appear. (p. 215)

H. G. Heneman (1985) included this component in his modified model of the antecedents of pay satisfaction without comment. Later, Miceli and Lane (1991) eliminated this component from their model of the antecedents of pay satisfaction, again without comment. Thus, any decision about whether to include this component in the theoretical model must be based on the theoretical arguments of Lawler (1971) and be informed by subsequent empirical research. We interpret Lawler's (1971) work to suggest that people use their perceptions of the pay of referent others to evaluate their level of pay rather than as a determinant of the perceived amount of pay they receive. Lawler continued his discussion of this component of the model by suggesting, "The more salary a person perceives his referent other as receiving, the more dissatisfied he will be with his own present pay" (p. 217). Thus, we include perceived pay of referent others in the general category of perceived inputs and outcomes of referent others as a determinant of the perceived amount of pay that should be received (Box 7) rather than as a determinant of the perceived amount of pay received.

\section{Correlates (Box 9)}

Recently, researchers have argued for the incorporation of organizational justice into the study of pay satisfaction (H. G. Heneman \& Judge, 2000; Miceli \& Lane, 1991). Although several authors have speculated about the relations between justice perceptions and pay satisfaction (H. G. Heneman \& Judge, 2000; Miceli \& Lane, 1991; Scarpello, 1988), the role of justice constructs as antecedents or consequences of pay satisfaction has not been clearly described. Distributive justice concerns the fairness of outcome distributions or allocations. Although outcome fairness is not synonymous with pay level satisfaction (Miceli \& Lane, 1991; Scarpello \& Jones, 1996), the two constructs are conceptually related. Thus, we expect a strong positive relation between distributive justice and pay level satisfaction. Several authors (e.g., Dyer \& Theriault, 1976; H. G. Heneman, 1985; Miceli \& Lane, 1991) have noted the important relations between pay administration processes and pay level satisfaction. To the extent that employees perceive the pay processes operating within their organizations as fair (i.e., procedural justice), we expect them to be more satisfied with their pay level. 


\section{Consequences (Box 10)}

H. G. Heneman and Judge (2000) noted that "research has unequivocally shown that pay dissatisfaction can have important and undesirable impacts on numerous employee outcomes. We need to make further exploration and identification of these pay dissatisfaction-outcome linkages a high priority for future research" (p. 85). H. G. Heneman and Judge (2000) used equity theory to suggest relations between pay dissatisfaction and both cognitive and behavioral consequences, so we expanded the pay level model shown in Figure 1 to include modifiable individual outcomes that have been linked to pay level satisfaction: (a) employee withdrawal cognitions and behaviors in terms of turnover intentions, absenteeism, and voluntary turnover and (b) job performance.

Although the literature on pay level satisfaction consequences is meager compared with the literature on antecedents, researchers have studied the relations between these consequences and the more general construct of job satisfaction. Of these consequences, turnover intentions are most strongly related to job satisfaction (e.g., Tett \& Meyer, 1993). Therefore, we expect a strong negative relation between turnover intentions and pay level satisfaction. We expect the relation between absenteeism and pay level satisfaction to be weak and negative (Eby, Freeman, Rush, \& Lance, 1999; Kinicki et al., 2002; Scott \& Taylor, 1985). Voluntary turnover is strongly (and negatively) related to job satisfaction (Spector, 1997), but because pay satisfaction represents satisfaction with only one aspect of the job, we expect a weaker, negative relation between turnover and pay level satisfaction (Eby et al., 1999; Kinicki et al., 2002). Two estimates of the population correlation between pay level satisfaction and job performance are available. Iaffaldano and Muchinsky (1985) found an overall relation of .06, whereas Kinicki et al. (2002) found a relation of .15 between supervisor ratings of performance and the JDI pay level satisfaction measure. Although results indicate that moderators of the pay level satisfaction-performance relation exist, neither study examined potential moderators. We examine potential moderators of this relation.

\section{Method}

\section{Search for Primary Data}

We began with an automated search of PsycINFO (Psychological Abstracts) and $\mathrm{ABI} / \mathrm{Inform}$ using the key words compensation satisfaction, pay satisfaction, compensation equity, pay equity, compensation fairness, and pay fairness. We also searched manually 12 journals for the years 1960 through 2003: Academy of Management Journal, Administrative Science Quarterly, Human Relations, Industrial and Labor Relations Review, Industrial Relations, Journal of Applied Psychology, Journal of Management, Journal of Organizational Behavior, Journal of Occupational and Organizational Psychology, Journal of Vocational Behavior, Organizational Behavior and Human Decision Processes, and Personnel Psychology. We chose the year 1960 to begin this search because the first formal attempts to measure pay satisfaction (e.g., the JDI; Smith et al., 1969) and the first theories of pay satisfaction (e.g., Lawler, 1971) were developed in the 1960s and early 1970s, and we were unaware of any empirical work on pay level satisfaction before that time. We also examined the empirical studies that included pay level satisfaction for references to other publications or articles that might have included pay level satisfaction. These processes identified over 1,800 conceptual and empirical publications, conference papers, technical reports, dissertations, books, and book chapters. We examined all published sources for the presence of usable data; however, we included only sources that were published in English. In addition, we requested copies of conference papers from authors.

\section{Decision Rules}

We included studies in the meta-analysis on the basis of several criteria. First, a study needed to present either a correlation coefficient between pay satisfaction and a correlate or quantitative data that we could use to calculate a correlation coefficient. (If correlation coefficients or data necessary to compute them were not presented in the article, we contacted the authors for additional data.) Second, participants needed to be adults employed full or part time or adult experimental participants who were paid for their work. Third, when we identified multiple studies that presented data for the same correlates from the same sample or samples, we included each correlate only once. Fourth, we excluded lagged correlations (i.e., correlations that were calculated on the basis of data collected at two different points in time). The only exception to this criterion was for absenteeism and turnover data, which are necessarily collected over a period of time. Lagged correlations are likely to differ from correlations based on data obtained at the same point in time because of unknown factors that may influence the constructs over the time interval. Because there were an insufficient number of lagged correlations to enable us to examine this factor as a potential moderator, we decided to exclude the samples that reported lagged correlations. Fifth, given our concern with construct validity, we excluded all studies for which we were unable to determine the actual items used to measure either pay satisfaction or one of its correlates. Sixth, we excluded samples that presented data at the group level of analysis (Ostroff \& Harrison, 1999). Seventh, in some studies researchers did not present a correlation matrix but chose to report selected correlations within the text. In these cases, we excluded studies in which the authors reported only significant correlations (Rothstein \& McDaniel, 1989).

\section{Pay Satisfaction Measures}

Table 1 shows the classification of published scales according to whether they measured pay level or general pay satisfaction. We made this determination on the basis of whether the items referred specifically to pay level or salary level (the amount of pay) or whether more than one item referred to an aspect of pay other than pay level. For example, the four items included in the pay level dimension of the Pay Satisfaction Questionnaire (PSQ; H. G. Heneman \& Schwab, 1985) refer to "salary" and "take-home pay"; thus, we classified the PSQ as a measure of pay level satisfaction. In addition, all Minnesota Satisfaction Questionnaire (MSQ; Weiss, Dawis, England, \& Lofquist, 1967) items refer to "pay," so we also classified the MSQ as a pay level measure. Eight of the nine items in the JDI refer to income or pay, although one item refers to "satisfactory profit sharing." We classified the JDI as a pay level satisfaction measure because the profit sharing item represented only $11 \%$ of the scale content. Our classification is consistent with H. G. Heneman (1985), who concluded that both the MSQ and the JDI are primarily measures of pay level satisfaction. We assigned the other pay level satisfaction scales included in Table 1 on the basis of the decision rule described above.

We classified the Index of Organizational Reactions: Financial (Dunham, Smith, \& Blackburn, 1977) and the combined 18-item PSQ as measures of general pay satisfaction because each scale includes more than 1 item that assesses a component of compensation other than pay level. The Job Diagnostic Survey (JDS; Hackman \& Oldham, 1974) represents a special case. We excluded from these analyses measures whose items all explicitly addressed pay fairness; however, we included the pay measure 
Table 1

Reliability Distributions for Pay Satisfaction Measures

\begin{tabular}{|c|c|c|c|c|c|c|}
\hline Name and source of scale & $\begin{array}{c}\text { No. alpha } \\
\text { reliabilities } \\
\text { available }\end{array}$ & $N$ & $\begin{array}{l}\text { Sample-size-weighted } \\
\text { mean } \alpha\end{array}$ & $\begin{array}{l}\text { Minimum } \\
\quad \alpha\end{array}$ & $\begin{array}{l}\text { Maximum } \\
\quad \alpha\end{array}$ & $\begin{array}{l}\text { Median } \\
\quad \alpha\end{array}$ \\
\hline All multi-item pay level satisfaction scales & 126 & 53,823 & .82 & .64 & .97 & .82 \\
\hline Job Descriptive Index: Pay (Smith et al., 1969) & 56 & 18,594 & .78 & .64 & .91 & .79 \\
\hline $\begin{array}{l}\text { Pay Satisfaction Questionnaire: Pay level (H.G. } \\
\text { Heneman \& Schwab, 1985) }\end{array}$ & 19 & 11.659 & 92 & .75 & 97 & .96 \\
\hline Minnesota Satisfaction Questionnaire: & & & & & & \\
\hline Compensation (Weiss et al., 1967) & 14 & 4,328 & .83 & .76 & .94 & .85 \\
\hline INDSALES: Pay (Churchill et al., 1974) & 3 & 461 & .88 & .85 & .89 & .88 \\
\hline Opinion Scale for Manager's Job Satisfaction: & & & & & & \\
\hline Pay (Warr \& Routledge, 1969) & 4 & 6,619 & .74 & .74 & .75 & .74 \\
\hline Worker Opinion Survey: Pay (Cross, 1973) & 4 & 749 & .83 & .79 & .86 & .83 \\
\hline $\begin{array}{l}\text { Pay Attitude Summary Index (Cammann et al., } \\
\text { 1983) }\end{array}$ & 4 & 1,863 & .92 & .90 & .93 & .92 \\
\hline $\begin{array}{l}\text { Multi-item pay level scales not otherwise } \\
\text { classified }\end{array}$ & 22 & 9,550 & .79 & .65 & .94 & .83 \\
\hline $\begin{array}{l}\text { All multi-item general pay satisfaction scales } \\
\text { Job Diagnostic Survey: Pay (Hackman \& }\end{array}$ & 38 & 33,756 & .84 & .68 & .95 & .85 \\
\hline Oldham, 1974) & 16 & 19,308 & .86 & .75 & .88 & .86 \\
\hline $\begin{array}{l}\text { Index of Organizational Reactions: Financial } \\
\text { (Dunham et al., 1977) }\end{array}$ & 3 & 2,059 & .75 & .74 & .77 & .74 \\
\hline $\begin{array}{l}\text { Pay Satisfaction Questionnaire: Total (H.G. } \\
\text { Heneman \& Schwab, 1985) }\end{array}$ & 4 & 1,798 & .93 & .87 & .95 & .93 \\
\hline $\begin{array}{l}\text { Multi-item general pay satisfaction scales not } \\
\text { otherwise classified }\end{array}$ & 15 & 10,591 & .82 & .68 & .95 & .82 \\
\hline
\end{tabular}

Note. The reliability of a single-item measure of pay level satisfaction was estimated to be .41 . The reliability of a single-item measure of general pay satisfaction was estimated to be .70 . INDSALES $=$ a measure of job satisfaction for the industrial sales force.

from the JDS as a measure of general pay satisfaction because 1 item refers to pay fairness (i.e., "the degree to which I am fairly paid for what I contribute to this organization") and the other item assesses general pay satisfaction (i.e., "the amount of pay and fringe benefits I receive"). We placed the ad hoc scales with content that extended beyond pay level in the general pay satisfaction category.

\section{Coding}

For consistency, Margaret L. Williams coded all the sources containing empirical data. We chose a random sample of approximately $16 \%$ of the included studies to check the accuracy of coding (324 relations from 43 samples from 32 studies). Nhung T. Nguyen independently coded these studies. The results of this check indicated that both raters agreed on sample size $99.7 \%$ of the time (on 322 of 324 occurrences) and agreed on the correlate to code and the value of the correlation coefficient $97.2 \%$ of the time (on 315 of 324 occurrences). We corrected any discrepancies found prior to conducting the meta-analysis. These high levels of agreement for sample sizes and correlation coefficients are consistent with past reliability studies of these variables (Whetzel \& McDaniel, 1988). An additional coder examined approximately $12 \%$ of the studies (24 of 203) to classify coded variables into the appropriate construct categories. We identified 1 study in which the primary coder misclassified a variable. Again, we corrected this situation prior to conducting the analyses.

In some cases, correlations were not provided but we were able to calculate a correlation coefficient from other statistics provided in the study. We used transformations provided by Hunter and Schmidt (1990, pp. 271-273) to calculate (a) a between-groups standardized mean difference $(d)$ when we knew means and standard deviations of two groups and (b) a correlation when we knew either the between-groups standardized mean difference or the between-groups $t$. We used procedures described by Dunlap, Cortina, Vaslow, and Burke (1996) for correlated designs. We corrected the correlations obtained from these transformations for dichotomization using formulas provided by Hunter and Schmidt (1990, pp. 46-47) when the correlates were not naturally occurring dichotomies (e.g. gender). We calculated phi coefficients from data provided in four studies (Bergmann, 1981; Penzer, 1969; Swan, Futrell, \& Todd, 1978; A. Williams, Livy, Silverstone, \& Adams, 1979). On the basis of the recommendation of an anonymous reviewer, we did not correct these phi coefficients.

Some studies presented data from more than one measure of pay satisfaction. If correlations among the multiple measures of pay satisfaction were provided, we calculated the correlation between a composite (i.e., the multiple measures of pay satisfaction) and an outside variable (i.e., the correlate) using the standard-score form of the equation provided by Ghiselli, Campbell, and Zedeck (1981, p. 163). If correlations among the multiple measures of pay satisfaction (which are necessary to calculate the correlation between the composite and the outside variable) were not provided, we randomly selected a single correlation for use in the metaanalysis (Martinussen \& Bjornstad, 1999). If data were available for the same correlates from more than one time period, we coded the first time period.

We only analyzed correlates for which data were available from six or more samples. (Note, however, that subgroup analyses for some correlates are based on fewer than seven samples.) This yielded a total of 28 antecedents, correlates, and consequences of pay satisfaction (see Tables 2 , $3,4,5$, and 6) found in 240 samples from 203 studies. A large majority of these studies (199 of 203 studies, or $98 \%$ of the total) were published in refereed outlets. We believe that in this situation, however, the file-drawer problem is less of a concern than it is for many meta-analyses. The majority of these studies did not focus on pay satisfaction; instead, pay satisfaction was included simply because the researchers administered and reported results for the entire JDI or JDS (e.g., Stone, 1976). Thus, whether the correlations for pay satisfaction were significant was unrelated to the decision to publish the research. 
Table 2

Meta-Analyses of Pay Discrepancy, Performance Reward Contingency, and Non-Job-Related Inputs With Pay Satisfaction

\begin{tabular}{|c|c|c|c|c|c|c|c|}
\hline \multirow[b]{2}{*}{ Distribution } & \multirow[b]{2}{*}{$k$} & \multirow[b]{2}{*}{$N$} & \multicolumn{2}{|c|}{$\begin{array}{l}\text { Observed } \\
\text { distribution }\end{array}$} & \multicolumn{3}{|c|}{ Population distribution } \\
\hline & & & $\begin{array}{c}\text { Mean } \\
r\end{array}$ & $S D_{r}$ & $\rho$ & $\sigma_{\rho}$ & $\begin{array}{l}80 \% \text { credibility } \\
\text { interval }\end{array}$ \\
\hline \multicolumn{8}{|c|}{ Pay discrepancy correlates of pay satisfaction } \\
\hline All pay discrepancy coefficients (all are pay level) & 11 & 1,931 & -.42 & .12 & $-.54 *$ & .16 & $-.74--.33$ \\
\hline \multicolumn{8}{|c|}{ Performance-reward contingency correlates of pay satisfaction } \\
\hline All performance reward contingency coefficients & 17 & 12,500 & .31 & .20 & $.57 *$ & .41 & $.05-1.00^{\mathrm{a}}$ \\
\hline \multicolumn{8}{|c|}{ Age correlates of pay satisfaction } \\
\hline $\begin{array}{l}\text { All age coefficients } \\
\text { All coefficients except Steffy \& Jones (1990) and }\end{array}$ & 74 & 82,249 & .03 & .09 & $.04 *$ & .11 & $-.10-.19$ \\
\hline Ting (1996) & 72 & 37,892 & .04 & .11 & $.05^{*}$ & .12 & $-.10-.21$ \\
\hline Pay level satisfaction & 61 & 74,761 & .03 & .09 & $.04 *$ & .11 & $-.10-.18$ \\
\hline Pay level coefficients without Steffy \& Jones & & & & & & & \\
\hline (1990) and Ting (1996) & 59 & 30,404 & .04 & .10 & $.05 *$ & .11 & $-.09-.19$ \\
\hline General pay satisfaction & 13 & 7,488 & .07 & .14 & $.08 *$ & .15 & $-.12-.26$ \\
\hline
\end{tabular}

Marital status correlates of pay satisfaction

All marital status coefficients

8

5,750

.01

.08

$.01 *$

.08

$-.09-.12$

Gender correlates of pay satisfaction

\author{
All gender coefficients \\ All coefficients except Steffy \& Jones (1990) and \\ Ting (1997) \\ Pay level \\ Pay level coefficients without Steffy \& Jones \\ (1990) and Ting (1997) \\ General pay satisfaction
}

$\begin{array}{lllllll}58 & 88,008 & .01 & .08 & .01 * & .10 & -.12-.13 \\ 56 & 48,530 & .03 & .08 & .04 * & .09 & -.07-.15 \\ 48 & 74,947 & .01 & .08 & .01 * & .10 & -.12-.13 \\ 46 & 35,469 & .04 & .09 & .04^{*} & .09 & -.07-.23 \\ 10 & 13,061 & .02 & .07 & .02 * & .07 & -.07-.11\end{array}$

Ethnicity correlates of pay satisfaction

\begin{tabular}{|c|c|c|c|c|c|c|c|}
\hline All ethnicity coefficients & 11 & 43,174 & .17 & .22 & $.25 *$ & .33 & $-.17-.68$ \\
\hline All coefficients except Ting (1997) & 10 & 12,336 & .45 & .25 & $.67 *$ & .39 & $.17-1.00^{\mathrm{a}}$ \\
\hline All coefficients except Steffy \& Jones (1990) & 10 & 34,534 & .06 & .02 & $.09 *$ & .02 & $.06-.11$ \\
\hline
\end{tabular}

Note. The reliabilities of age, marital status, gender, and ethnicity are assumed to be 1.00. No estimates of the reliability of pay discrepancy were available, so the reliability of pay discrepancy was set at .80. The reliability of pay satisfaction was interpolated for 9 of 11 pay discrepancy samples: Five were single-item pay level satisfaction measures, and 2 were pay level satisfaction composites $(\alpha \mathrm{s}=.93$ and .85). The reliability of performance reward contingency was interpolated for 7 of 17 samples: All were single-item measures $(\alpha=.44)$. (The weighted average $\alpha$ was .77 for the multi-item measures.) The reliability of pay satisfaction was interpolated for 6 of 17 performance reward contingency samples: Five were single-item pay level satisfaction measures. For age, the reliability of pay satisfaction was interpolated for 32 of 74 samples: Fourteen were single-item pay level measures, 1 was a pay level composite $(\alpha=.93)$, and 1 was a single-item general pay satisfaction measure. For marital status, the reliability of pay satisfaction was interpolated for 1 of 8 samples: a single-item measure of pay level satisfaction. For gender (male $=0$, female $=1$ ), the reliability of pay satisfaction was interpolated for 26 of 58 samples: Thirteen were single-item pay level satisfaction measures, and 1 was a single-item general pay satisfaction measure. For ethnicity (non-White $=0$, White $=1$ ), the reliability of pay satisfaction was interpolated for 5 of 11 samples: Two were single-item pay level satisfaction measures. ${ }^{\text {a }}$ The upper range of the credibility interval was rounded down to 1.00.

$* p<.05$ for the chi-square test for homogeneity of corrected correlations.

\section{Analysis}

We used psychometric meta-analysis (Hunter \& Schmidt, 1990) in which we individually corrected each coefficient for unreliability of the pay satisfaction measure and the correlate. (We did not correct for range variance.) When the reliability of the pay satisfaction measure was reported in the study, we used that reliability. When the reliability of the pay satisfaction measure was not reported, we used the sample-size-weighted mean of the reliability from those studies that reported reliabilities for the same pay satisfaction measure (see Table 1). We grouped the multi-item ad hoc measures into pay level satisfaction and general pay satisfaction groups. If a study did not report a reliability for a multi-item ad hoc pay satisfaction measure, we used the sample-size-weighted mean of multiitem ad hoc scales that reported a reliability (shown in Table 1). In several cases, we used a composite of two or more pay satisfaction scales. We calculated the reliability of the composite using equations for the reliability of linear combinations provided by Nunnally (1978, p. 249). 
Table 3

Meta-Analyses of Job-Related Inputs With Pay Satisfaction

\begin{tabular}{|c|c|c|c|c|c|c|c|}
\hline \multirow[b]{2}{*}{ Distribution } & \multirow[b]{2}{*}{$k$} & \multirow[b]{2}{*}{$N$} & \multicolumn{2}{|c|}{$\begin{array}{c}\text { Observed } \\
\text { distribution }\end{array}$} & \multicolumn{3}{|c|}{ Population distribution } \\
\hline & & & $\begin{array}{c}\text { Mean } \\
r\end{array}$ & $S D_{r}$ & $\rho$ & $\sigma_{\rho}$ & $\begin{array}{l}80 \% \text { credibility } \\
\text { interval }\end{array}$ \\
\hline \multicolumn{8}{|c|}{ Education correlates of pay satisfaction } \\
\hline All education coefficients & 47 & 62,000 & .01 & .07 & $.01 *$ & .08 & $-.08-.11$ \\
\hline All coefficients except Ting (1996) & 46 & 26,283 & .00 & .10 & $.00 *$ & .12 & $-.15-.15$ \\
\hline Pay level satisfaction & 39 & 59,519 & .00 & .07 & $.01 *$ & .08 & $-.09-.11$ \\
\hline Pay level satisfaction without Ting (1996) & 38 & 23,802 & .01 & .10 & .00 & .12 & $-.15-.16$ \\
\hline General pay satisfaction & 8 & 2,481 & -.02 & .04 & -.02 & .00 & $-.02--.02$ \\
\hline
\end{tabular}

Experience correlates of pay satisfaction

\begin{tabular}{lcccccccc} 
All experience coefficients & 9 & 3,028 & .07 & .12 & $.08^{*}$ & .11 & $-.07-.22$ \\
\hline & Job level correlates of pay satisfaction & & & & & \\
& & & & & & \\
& 23 & 48,775 & .16 & .07 & $.23^{*}$ & .09 & $.11-.35$ \\
All job level coefficients & 22 & 13,058 & .12 & .12 & $.13^{*}$ & .13 & $-.04-.29$ \\
All coefficients except Ting (1996)
\end{tabular}

Job tenure correlates of pay satisfaction

All job tenure coefficients

$21-11,796-.03$

$\begin{array}{llll}.10 & -.03^{*} \quad .11 & -.17-.11\end{array}$

Organizational tenure correlates of pay satisfaction

\begin{tabular}{lrrrrrrr} 
All organizational tenure coefficients & 44 & 36,692 & .10 & .16 & $.15^{*}$ & .23 & $-.14-.44$ \\
All coefficients except Steffy \& Jones (1990) & 43 & 28,052 & .03 & .09 & $.03^{*}$ & .11 & $-.11-.18$ \\
Pay level satisfaction & 37 & 29,516 & .12 & .16 & $.18^{*}$ & .24 & $-.13-.49$ \\
Pay level satisfaction without Steffy \& Jones (1990) & 36 & 20,876 & .03 & .10 & $.04 *$ & .13 & $-.12-.20$ \\
General pay satisfaction & 7 & 7,176 & .01 & .07 & $.01^{*}$ & .06 & $-.07-.09$ \\
\hline
\end{tabular}

Note. The reliabilities of education, experience, job level, job tenure, and organizational tenure were assumed to be 1.00. For education, the reliability of pay satisfaction was interpolated for 16 of 47 samples: Nine were single-item pay level satisfaction measures, and 1 was a pay level composite $(\alpha=$ .93). For experience, the reliability of pay satisfaction was interpolated for two of 9 samples. For job level, the reliability of pay satisfaction was interpolated for 11 of 23 samples: Two were single-item pay level satisfaction measures, and 1 was a pay level satisfaction composite $(\alpha=.93)$. For job tenure, the reliability of pay satisfaction was interpolated for 3 of 21 samples: One was a single-item pay level satisfaction measure, and 1 was a pay level composite $(\alpha=.93)$. For organizational tenure, the reliability of pay satisfaction was interpolated for 19 of 44 samples: Eight were single-item pay level satisfaction measures, and 1 was a single-item general pay satisfaction measure.

$* p<.05$ for the chi-square test for homogeneity of corrected correlations.

We used the information in Table 1 to calculate reliability estimates for single-item measures of pay level and general pay satisfaction. For each published scale listed in Table 1, we used the Spearman-Brown formula to estimate the reliability of a single-item measure. We then weighted these estimates by the total sample size for each scale (shown in Column 3 of Table 1) and calculated two sample-size-weighted average reliability estimates for single-item measures-one for pay level satisfaction $(\alpha=.44)$, and one for general pay satisfaction $(\alpha=.70)$.

We fixed the reliabilities of 13 correlates at 1.00, assuming they were measured without error (age, marital status, gender, ethnicity, education, experience, job level, job tenure, organizational tenure, salary, pay raise percentage, absenteeism, and voluntary turnover). No estimates of reliability were available for pay discrepancy; however, it is unlikely that this variable is measured without error. Thus, we fixed the reliability of pay discrepancy at .80 . For the remaining correlates, we used the reliabilities reported in the studies or imputed reliabilities the same way we did for the pay satisfaction measures. The number of estimated reliabilities for each of the correlates as well as the value of the sample-size-weighted mean reliability coefficient and the reliability estimates for single-item measures are given in the notes to Tables 2-6 where appropriate. The number of composites included in each analysis is shown in the notes for Tables 2-6.
We set the reliability of job performance to .52 on the basis of Viswesvaran, Ones, and Schmidt's (1996) meta-analysis of job performance ratings.

Whereas we imputed missing reliabilities with means or otherwise set them to constants, the variance of the reliabilities is likely to be smaller than the variance of the reliabilities in the population. This will cause the estimates of the standard deviation of the population correlations to be upwardly biased and will cause the credibility interval to be wider than it would be if the variance of the reliabilities across studies were more accurately estimated. The effect of this bias is that more of the population variance may be attributed to moderators than is actually the case. The imputed reliabilities, when correct on average, will not bias the estimated means of the population correlations.

To examine the impact on the meta-analytic results of studies with large sample sizes, we ran each analysis with and without studies whose samples sizes exceeded either 6,000 or $33 \%$ of the total sample size for each correlate. These results are reported in Tables 2-6.

Although pay level satisfaction measures predominated over general pay satisfaction measures, we examined type of pay satisfaction measure as a moderator. We compared the results obtained from the studies using pay level satisfaction measures with the results from studies that used general pay satisfaction measures only when $k>6$ for both subgroups. These 
Table 4

Meta-Analyses of Perceived Job Characteristics With Pay Satisfaction

\begin{tabular}{|c|c|c|c|c|c|c|c|}
\hline \multirow[b]{2}{*}{ Distribution } & \multirow[b]{2}{*}{$k$} & \multirow[b]{2}{*}{$N$} & \multicolumn{2}{|c|}{$\begin{array}{c}\text { Observed } \\
\text { distribution }\end{array}$} & \multicolumn{3}{|c|}{ Population distribution } \\
\hline & & & $\begin{array}{c}\text { Mean } \\
r\end{array}$ & $S D_{r}$ & $\rho$ & $\sigma_{\rho}$ & $\begin{array}{l}80 \% \text { credibility } \\
\text { interval }\end{array}$ \\
\hline \multicolumn{8}{|c|}{ Job autonomy correlates of pay satisfaction } \\
\hline All autonomy coefficients & 15 & 11,443 & .18 & .06 & $.24 *$ & .06 & $.16-.32$ \\
\hline All autonomy correlates except Tiegs et al. (1992) & 14 & 5,038 & .14 & .07 & $.19^{*}$ & .06 & $.11-.27$ \\
\hline JDI pay level satisfaction ${ }^{\mathrm{a}}$ & 8 & 2,260 & .11 & .08 & $.16^{*}$ & .07 & $.07-.25$ \\
\hline \multicolumn{8}{|c|}{ Skill variety correlates of pay satisfaction } \\
\hline All skill variety coefficients & 13 & 11,595 & .12 & .06 & $.18^{*}$ & .12 & $.02-.33$ \\
\hline All skill variety correlates except Tiegs et al. (1992) & 12 & 5,190 & .16 & .07 & $.25^{*}$ & .15 & $.06-.45$ \\
\hline JDI pay level satisfaction ${ }^{\mathrm{a}}$ & 6 & 2,039 & .14 & .07 & .19 & .06 & $.11-.27$ \\
\hline
\end{tabular}

Task feedback correlates of pay satisfaction

\begin{tabular}{lrrrrrrrr} 
All task feedback coefficients & 11 & 9,629 & .19 & .05 & $.24 *$ & .04 & $.20-.29$ \\
All feedback correlates except Tiegs et al. (1992) & 10 & 3,224 & .18 & .08 & $.23 *$ & .06 & $.15-.32$ \\
JDI pay level satisfaction $^{\mathrm{a}}$ & 5 & 1,172 & .10 & .05 & .13 & .00 & $.13-.13$ \\
\hline
\end{tabular}

Task identity correlates of pay satisfaction

\begin{tabular}{lrrrrrrr} 
All task identity coefficients & 11 & 9,625 & .08 & .04 & .11 & .03 & $.07-.15$ \\
All task identity correlates except Tiegs et al. (1992) & 10 & 3,220 & .12 & .06 & .16 & .00 & $.16-.16$ \\
JDI pay level satisfaction $^{\mathrm{a}}$ & 5 & 1,172 & .14 & .02 & .20 & .00 & $.20-.20$ \\
\hline
\end{tabular}

Task significance correlates of pay satisfaction

\begin{tabular}{lrrrrrrr} 
All task significance coefficients & 7 & 8,101 & .10 & .04 & .14 & .03 & $.10-.17$ \\
All task significance correlates except Tiegs et al. (1992) & 6 & 1,696 & .14 & .07 & .19 & .04 & $.13-.24$ \\
JDI pay level satisfaction $^{\mathrm{a}}$ & 3 & 302 & .01 & .02 & .02 & .00 & $.02-.02$ \\
\hline
\end{tabular}

Job scope correlates of pay satisfaction

$\begin{array}{lrrrrrrrr}\text { All job scope coefficients } & 10 & 9,051 & .21 & .05 & .26 * & .04 & .21-.31 \\ \text { All job scope correlates except Oldham et al. (1979) } & 9 & 2,121 & .16 & .09 & .23 & .08 & .14-.32\end{array}$

Note. The reliability of autonomy was interpolated for 7 of 15 samples: All were multi-item measures $(\alpha=.67)$. The reliability of pay satisfaction was interpolated for 9 of 15 autonomy samples: One was a single-item general pay satisfaction measure. The reliability of skill variety was interpolated for 6 of 13 samples: One was a single-item measure $(\alpha=.45) ; 5$ were for multi-item measures $(\alpha=.72)$. The reliability of pay satisfaction was interpolated for 7 of 13 skill variety samples: One was a single-item pay level satisfaction measure. The reliability of task feedback was interpolated for 5 of 11 samples: All were multi-item measures $(\alpha=.70)$. The reliability of pay satisfaction was interpolated for 6 of the 11 task feedback samples. The reliability of task identity was interpolated for 5 of 11 samples: All were multi-item measures $(\alpha=.65)$. The reliability of pay satisfaction was interpolated for 6 of the 11 task identity samples. The reliability of task significance was interpolated for 3 of 7 samples: All were multi-item measures $(\alpha=.61)$. The reliability of pay satisfaction was interpolated for 3 of the 7 task significance samples. The reliability of job scope was interpolated for 6 of 10 samples: All were multi-item scales $(\alpha=.77)$. The reliability of pay satisfaction was interpolated for 6 of the 10 job scope samples: Two were single-item pay level satisfaction measures. JDI $=$ Job Descriptive Index.

${ }^{a}$ Included for comparison with Kinicki et al. (2002).

$* p<.05$ for the chi-square test for homogeneity of corrected correlations.

results are reported in Tables 2, 3, 5, and 6. For comparison purposes, we present results for the subgroup of samples that used the JDI for the eight correlates that our study has in common with Kinicki et al. (2002; see Tables 4 and 6). We calculated Hunter and Schmidt's (1990, p. 151) chi-square test for homogeneity of corrected correlations for each corrected correlation $(\rho)$ shown in Tables 2-6.

\section{Results}

Two comments regarding our overall results are warranted. First, we examined the type of pay satisfaction measure (i.e., level vs. general) as a moderator for seven correlates. Out of seven correlates, five did not show any differences across type of pay satisfaction measure. We found differences for two correlates (distributive justice and performance), which indicates that, in some situations, the focus of the pay satisfaction measure may influence the results. Second, the results of the significance tests indicated heterogeneity of correlations within almost all of the distributions. Thus, potential moderators exist for the majority of correlates included in the meta-analysis, even those that are not strongly related to pay level satisfaction (e.g., job-related inputs). We examined moderators for some of these relations. 
Table 5

Meta-Analyses of Standards of Comparison, Actual Pay and Pay Raises, and Remaining Antecedents With Pay Satisfaction

\begin{tabular}{|c|c|c|c|c|c|c|c|}
\hline \multirow[b]{2}{*}{ Distribution } & \multirow[b]{2}{*}{$k$} & \multirow[b]{2}{*}{$N$} & \multicolumn{2}{|c|}{$\begin{array}{c}\text { Observed } \\
\text { distribution }\end{array}$} & \multicolumn{3}{|c|}{ Population distribution } \\
\hline & & & $\begin{array}{c}\text { Mean } \\
r\end{array}$ & $S D_{r}$ & $\rho$ & $\sigma_{\rho}$ & $\begin{array}{l}80 \% \text { credibility } \\
\text { interval }\end{array}$ \\
\hline
\end{tabular}

Internal comparisons (employees within the same organization) correlates of pay satisfaction

\begin{tabular}{lllllllllll} 
All internal comparison coefficients & 12 & 11,563 & .56 & .05 & $.94 *$ & .14 & $.76-1.00^{\mathrm{a}}$ \\
\hline
\end{tabular}

External comparisons (employees from other organizations) correlates of pay satisfaction

\begin{tabular}{llllllllll} 
All external comparison coefficients & 14 & 12,986 & .57 & .09 & $1.00^{\mathrm{b} *}$ & .30 & $.93-1.00^{\mathrm{a}}$ \\
\hline
\end{tabular}

General comparisons (referents of the same age, education, etc.) correlates of pay satisfaction

\begin{tabular}{lccccccc} 
All general comparison coefficients & 6 & 3,009 & .40 & .14 & $.75 *$ & .13 & \\
\hline & \multicolumn{7}{c}{ Pay level correlates of pay satisfaction } \\
All pay level coefficients & 64 & 29,754 & .26 & .14 & $.29 *$ & .16 \\
Pay level satisfaction & 54 & 21,829 & .25 & .15 & $.29 *$ & .17 & $.09-.49$ \\
General pay satisfaction & 10 & 7,925 & .27 & .11 & $.29 *$ & .11 & $.08-.51$ \\
\hline
\end{tabular}

Pay raise percentage correlates of pay satisfaction

$\begin{array}{lllllllllllllll}\text { All pay raise percentage coefficients } & 6 & 6 & 2,182 & .07 & .04 & .08 & .08 & .08 & .08\end{array}$

Note. The reliabilities of salary and percentage pay raise were assumed to be 1.00 . The reliability of internal comparisons was interpolated for 10 of 12 samples: All were single-item measures $(\alpha=.67)$. $(\alpha=.86$ for the one sample that used a multi-item measure.) The reliability of pay satisfaction was interpolated for 11 of 12 internal comparison samples: Six were single-item pay level satisfaction measures, and 1 was a single-item general pay satisfaction measure. The reliability of external comparisons was interpolated for 13 of 14 samples: All were single-item measures $(\alpha=.38)$. ( $\alpha=.55$ for the one sample that used a multi-item measure.) The reliability of pay satisfaction was interpolated for 10 of 14 external comparison samples: Seven were single-item pay level satisfaction measures. The reliability of general comparisons was interpolated for 3 of 6 samples: Two were single-item measures $(\alpha=$ .34 ), and 1 was a composite $(\alpha=.60)$. (The weighted average $\alpha=.61$ for the multi-item measures.) The reliability of pay satisfaction was imputed for 4 of 6 general comparison samples: All were single-item pay level satisfaction measures. For salary, the reliability of pay satisfaction was imputed for 26 of 64 samples: Two were pay level satisfaction composites $(\alpha \mathrm{s}=.85$ and .94$), 11$ were single-item pay level satisfaction measures, and 1 was a single-item general pay satisfaction measure. For pay raise percentage, the reliability of pay satisfaction was imputed for 1 of 6 samples.

${ }^{\mathrm{a}}$ The upper range of the credibility interval was rounded down to 1.00 . ${ }^{\mathrm{b}}$ The population correlation coefficient was rounded down to 1.00 .

$* p<.05$ for the chi-square test for homogeneity of corrected correlations.

\section{Primary Determinant: Discrepancy Between Perceived Amount of Pay That Should Be Received and Perceived Amount of Pay Received (Box 1)}

As shown in Table 2, strong support for discrepancy theory is provided by the relations between pay discrepancy and pay satisfaction. For all 11 samples, $\rho=-.54$. We had planned to examine whether the measure of discrepancy used in the primary study was consistent with equity or discrepancy theory, but confounds existed that eliminated this possibility.

\section{Antecedents}

Perceptions of pay policies and administration (Box 4). As shown in Table 2, employee perceptions of performance reward contingency were very strongly related to pay level satisfaction $(\rho=.57)$.

Perceived inputs: Non-job-related (Box 5). The results for non-job-related inputs are also shown in Table 2. Age and marital status were weakly related to pay level satisfaction $(\rho \mathrm{s}=.04$ and .01 , respectively). The population correlation between gender $(0=$ male, $1=$ female) and pay level satisfaction was .01 . Whereas we know that gender is related to actual pay level, we conducted an additional analysis that examined the partial correlation between gender and pay satisfaction, controlling for actual pay. We obtained a rho of -.17 between gender and actual pay required for this analysis from 24 samples included in the meta-analysis, with a total sample size of 17,306 . The partial correlation was .05 , indicating that once pay level was controlled, women were slightly more satisfied with their pay than are men, although mean differences are likely to be small. We found that ethnicity $(0=$ nonWhite, 1 = White) was moderately related to pay satisfaction, although the value for rho dropped from .25 to .09 with the removal of one study correlation that was an outlier (Steffy \& Jones, $1990 ; r=.61$ ). Therefore, we believe that .09 is a better estimate of the population value than .25 . We calculated a partial correlation between ethnicity and pay level satisfaction, controlling for pay level, to see whether pay differences between groups accounted for differences in pay level satisfaction. We used the population correlation of .09 between ethnicity and pay level satisfaction and a population correlation estimate of .06 between ethnicity and pay based on four samples with a total sample size of 2,901 (the four correlations were $.05, .05, .07$, and .08). The partial correlation was .07. The variance reduction rate (Chen \& Spector, 1991 ) indicated that approximately $40 \%$ of the shared variance 
Table 6

Meta-Analyses of Correlates and Consequences With Pay Satisfaction

\begin{tabular}{|c|c|c|c|c|c|c|c|}
\hline \multirow[b]{2}{*}{ Distribution } & \multirow[b]{2}{*}{$k$} & \multirow[b]{2}{*}{$N$} & \multicolumn{2}{|c|}{$\begin{array}{c}\text { Observed } \\
\text { distribution }\end{array}$} & \multicolumn{3}{|c|}{ Population distribution } \\
\hline & & & $\begin{array}{c}\text { Mean } \\
r\end{array}$ & $S D_{r}$ & $\rho$ & $\sigma_{\rho}$ & $\begin{array}{l}80 \% \text { credibility } \\
\text { interval }\end{array}$ \\
\hline \multicolumn{8}{|c|}{ Distributive justice correlates of pay satisfaction } \\
\hline All distributive justice coefficients & 10 & 6,595 & .61 & .10 & $.79 *$ & .12 & $.63-.94$ \\
\hline All distributive justice coefficients except M. Brown (2001) & 9 & 3,728 & .61 & .13 & $.84 *$ & .14 & $.66-1.00^{\mathrm{a}}$ \\
\hline Pay level satisfaction & 7 & 5,627 & .58 & .05 & $.75^{*}$ & .07 & $.66-.84$ \\
\hline Pay level satisfaction without Brown (2001) & 6 & 2,760 & .54 & .05 & $.78^{*}$ & .10 & $.66-.90$ \\
\hline General pay satisfaction & 3 & 968 & .80 & .07 & $1.00^{\mathrm{b} *}$ & .10 & $.88-1.00^{\mathrm{a}}$ \\
\hline
\end{tabular}

Procedural justice correlates of pay satisfaction

All procedural justice coefficients
Pay-focused procedural justice

General procedural justice

\begin{tabular}{lrlllll}
8 & 2,291 & .36 & .17 & $.42 *$ & .18 & $.19-.66$ \\
4 & 1,529 & .48 & .04 & .55 & .04 & $.50-.60$ \\
4 & 762 & .13 & .07 & .17 & .00 & $.17-.17$ \\
\hline
\end{tabular}

Turnover intentions correlates of pay satisfaction

\begin{tabular}{|c|c|c|c|c|c|c|c|}
\hline $\begin{array}{l}\text { All turnover intentions coefficients } \\
\text { JDI pay level satisfaction }\end{array}$ & $\begin{array}{l}37 \\
16\end{array}$ & $\begin{array}{r}15,983 \\
7,043\end{array}$ & $\begin{array}{l}-.21 \\
-.14\end{array}$ & .14 & $\begin{array}{l}-.31 * \\
-.20^{*}\end{array}$ & $\begin{array}{l}.20 \\
.18\end{array}$ & $\begin{array}{l}-.57--.05 \\
-.43-.03\end{array}$ \\
\hline \multicolumn{8}{|c|}{ Absenteeism correlates of pay satisfaction } \\
\hline All absenteeism coefficients & 22 & 2,257 & -.05 & .12 & $-.05^{*}$ & .08 & $-.16-.05$ \\
\hline JDI pay level satisfaction ${ }^{\mathrm{b}}$ & 15 & 1,349 & -.07 & .11 & -.08 & .06 & $-.15-.00$ \\
\hline
\end{tabular}

Voluntary turnover correlates of pay satisfaction

$9 \quad 1,362-.15$ $.12-.17^{*}$

$.10-.30--.04$

Performance correlates of pay satisfaction

\begin{tabular}{|c|c|c|c|c|c|c|c|}
\hline All performance coefficients & 43 & 14,848 & .03 & .11 & $.05^{*}$ & .13 & $-.12-.22$ \\
\hline Self-rated performance & 12 & 5,730 & .02 & .07 & $.03^{*}$ & .08 & $-.08-.14$ \\
\hline Supervisor-rated performance & 26 & 8,232 & .02 & .12 & $.04 *$ & .15 & $-.16-.24$ \\
\hline Objective performance measure & 4 & 711 & .22 & .08 & .25 & .04 & $.20-.30$ \\
\hline Pay level satisfaction & 33 & 12,884 & .04 & .11 & $.06^{*}$ & .14 & $-.12-.23$ \\
\hline JDI supervisor-rated performance ${ }^{b}$ & 16 & 3,837 & .11 & .10 & $.17 *$ & .13 & $.01-.34$ \\
\hline General pay satisfaction & 10 & 1,964 & .00 & .11 & $-.01 *$ & .10 & $-.14-.12$ \\
\hline
\end{tabular}

Note. The reliabilities of absenteeism and turnover are assumed to be 1.00 . The reliability of distributive justice was interpolated for 1 of 10 samples, a single-item measure $(\alpha=.62)$. (The weighted average $\alpha=.90$ for the multi-item measures.) The reliability of pay satisfaction was interpolated for 3 of 10 distributive justice samples: Two were single-item pay level satisfaction measures, and 1 was a single-item general pay satisfaction measure. The reliability of procedural justice was interpolated for 3 of 8 samples: One was a single-item measure $(\alpha=.56)$, and 2 were procedural justice composites ( $\alpha \mathrm{s}=.83$ and .95). (The weighted average $\alpha=.82$ for the multi-item measures.) The reliability of turnover intentions was interpolated for 23 of 37 samples: Eighteen were single-item measures $(\alpha=.56)$, and 5 were multi-item measures $(\alpha=.80)$. The reliability of pay satisfaction was interpolated for 20 of 37 turnover intentions samples: Five were single-item pay level satisfaction measures. For absenteeism, the reliability of pay satisfaction was interpolated for 14 of 22 samples. For voluntary turnover, the reliability of pay satisfaction was interpolated for 6 of 9 samples. The reliability of performance ratings was set at .52 (Viswesvaran, Ones, \& Schmidt, 1996). The reliability of objective performance measures was set at .95 . The reliability of pay satisfaction was interpolated for 27 of 43 performance samples: Four were single-item pay level satisfaction measures, and 1 was a pay level composite $(\alpha=.93)$. JDI $=$ Job Descriptive Index.

${ }^{\mathrm{a}}$ The upper bound of the credibility interval was rounded down to 1.00. ${ }^{\mathrm{b}}$ Included for comparison with Kinicki et al. (2002).

$* p<.05$ for the chi-square test for homogeneity of corrected correlations.

between pay level satisfaction and ethnicity was attributable to differences in actual pay.

Perceived inputs: Job related (Box 5). Table 3 shows the results for job-related inputs. Most of these results show weak relations between inputs and pay level satisfaction. Education was barely related to pay satisfaction $(\rho=.01)$. Work experience was only weakly related $(\rho=.08)$. Job level was moderately related to pay satisfaction $(\rho=.23)$, although the value for rho dropped to
.13 when we excluded Ting (1996; on the basis of the sample size of 35,717$)$. Job tenure was also barely related to pay satisfaction $(\rho=-.03)$. Organizational tenure was moderately related to pay satisfaction $(\rho=.15)$; however, this relation dropped to .03 with the removal of one large sample (Steffy \& Jones, 1990) whose correlation between organizational tenure and pay level satisfaction was an outlier $(r=.35)$. We calculated partial correlations between job-related inputs and pay level satisfaction, controlling 
for pay. In every case, the partial correlation was lower than the population correlation, and we found partial support for the theoretical prediction that job inputs would be weakly and negatively related to pay level satisfaction with pay held constant. For education, the partial correlation was -.06 ; for work experience, the partial correlation was .00. For job level, the partial correlation was .12 for the full sample and .00 without Ting (1996). The partial correlation for job tenure was -.08 , and it was -.06 for organizational tenure (with the exclusion of the outlier provided by Steffy \& Jones, 1990).

Perceived job characteristics (Box 6). As shown in Table 4, perceived job characteristics were moderately and positively related to pay satisfaction (rhos ranged from .11 to .24); autonomy and task feedback were the most strongly related to pay satisfaction. The population correlation for job scope (i.e., a combined rating of all job characteristics) was .26. The subsets of our distributions that used the JDI to measure pay level satisfaction can be compared with the results of Kinicki et al. (2002). For four job characteristics, the results were somewhat comparable $(\rho \mathrm{s}=.16$ vs. .22 for autonomy, .19 vs. .21 for skill variety, .13 vs. .14 for task feedback, and .20 vs. .23 for task identity). For task significance, Kinicki et al.'s (2002) analysis yielded a population correlation of .17, which contrasts with our result of .02. This difference may be a result of our decision to exclude studies in which participants were not actually paid. In Vance and Biddle (1985), participants were compensated with course credit only. When we added Vance and Biddle (1985) to our analysis, the population correlation increased to .16, a value very close to the .17 obtained by Kinicki et al. (2002).

We examined the possibility that the relations between job characteristics and pay level satisfaction could be explained by pay differences for skill variety and job scope. A review of the job design literature provided one correlation of .29 between skill variety and pay (Seybolt, 1976; $N=883$ ) and one correlation of .26 between job scope and wages (Youngblood, DeNisi, Molleston, \& Mobley, 1984; $N=400$ ). The resulting partial correlation between skill variety and pay level satisfaction, with pay controlled, was .10; for job scope it was .19. According to the variance reduction rate (Chen \& Spector, 1991), these values represent a reduction of the job characteristic-pay level satisfaction relation of $44 \%$ and $27 \%$, respectively.

Perceived inputs and outcomes of referent others (Box 7). Pay comparisons were among the strongest predictors of pay satisfaction. The values in Table 5 refer to employees' ratings of how well their current pay compared with either internal comparisons (i.e., employees within the same organization), external comparisons (i.e., employees doing similar work for other organizations), or general comparisons. This final category combined comparisons with others of the same age and with the same level of education; general social comparisons (e.g., the average worker in the United States); and a scale that included nine referents, such as internal and external comparisons as well as comparisons with previous jobs and generalized others (Summers \& DeNisi, 1990). The rhos for internal, external, and general comparisons were .94, 1.00, and .75 , respectively.

Actual pay and pay raises received (Box 8). Table 5 shows that actual pay was moderately related to both pay level satisfaction and general pay satisfaction ( $\rho \mathrm{s}=.29$ for both). The rho for percentage pay raise was .08 , which shows that percentage pay raise was weakly related to pay level satisfaction.

\section{Correlates (Box 9)}

As shown in Table 6, distributive justice was more strongly related $(\rho=.79)$ to pay satisfaction than was procedural justice $(\rho=.42)$. The type of pay satisfaction measure moderated the relation between distributive justice and pay level satisfaction such that the relation was stronger for general pay satisfaction measures ( $\rho=1.00)$ than for pay level satisfaction measures $(\rho=.75)$. In addition, the type of procedural justice measure moderated the relation between procedural justice and pay level satisfaction. The relation was stronger for pay-focused measures of procedural justice $(\rho=.55)$ than for more general measures of procedural justice $(\rho=.17)$.

\section{Consequences (Box 10)}

Table 6 shows that turnover intentions were moderately related to pay level satisfaction $(\rho=-.31)$. Absenteeism was weakly related to pay satisfaction $(\rho=-.05)$. Voluntary turnover was moderately related to pay level satisfaction $(\rho=-.17)$. Performance was weakly related to pay satisfaction $(\rho=.05)$, although this relation was partially moderated by the type of performance measure used. For objective performance measures, the population correlation was much stronger $(\rho=.25)$ than for self- or supervisor-rated performance ( $\rho \mathrm{s}=.03$ and .04 , respectively). Kinicki et al. (2002) examined three of these correlates, and Table 6 shows our results for the JDI for these three correlates. Even though our results are based on more than twice as many JDI samples as Kinicki et al.'s findings were, in all three cases our results are strikingly similar $(-.20$ vs. -.29 for turnover intentions, -.08 vs. -.11 for absenteeism, and .17 vs. .15 for supervisor-rated performance).

\section{Discussion}

Our discussion provides (a) an evaluation of theoretical and methodological issues related to the study of pay level satisfaction and (b) suggestions for future research directions. We again use Figure 1 as an organizing framework for our comments.

\section{Primary Determinant: Discrepancy Between Perceived Amount of Pay That Should Be Received and Perceived Amount of Pay Received (Box 1)}

We based our summary of the antecedents of pay level satisfaction on a model that combines equity theory and discrepancy theory (see Figure 1); however, we found that we could not evaluate a key component of this model. Although the discrepancy between perceived amount of pay that should be received and perceived amount of pay received was strongly and negatively related to pay level satisfaction, the role depicted in Figure 1 for this discrepancy as a mediator between other antecedents and pay level satisfaction has been ignored in empirical research. Most studies have examined direct relations between pay level satisfaction and the antecedents of both perceived amount of pay that should be received and perceived amount of pay received. (An 
example is inputs and outcomes of referent others, as we discuss below.) In light of the support for the predictive capacity of discrepancy provided by this meta-analysis and other research (e.g., Rice, McFarlin, \& Bennett, 1989), future research should examine this basic premise of mediation within discrepancy models, as M. L. Williams (1995) has for benefit level satisfaction.

We had planned to examine the competing views from equity theory and Miceli and Lane's (1991) interpretation of discrepancy theory regarding the relation between overreward and pay level satisfaction; however, despite the prominence of pay discrepancy in the theoretical model, only 11 samples were available for analysis. We examined each sample to determine whether the discrepancy was coded such that overreward was expected to be negatively or positively related to satisfaction. ${ }^{1}$ We found two conditions that made untenable the examination of operationalization of pay discrepancy as a moderator of the relation between pay discrepancy and pay level satisfaction. First, whether discrepancy was viewed as positively or negatively related to pay satisfaction was confounded with whether the studies used a rating scale or a difference score (e.g., the pay the employee should receive minus his or her actual pay) to assess discrepancy. Second, in two of the four samples that coded discrepancy so that overreward was positively related to pay level satisfaction, the authors reported that no respondent reported making more than he or she should. Thus, these samples did not provide an adequate test of the impact of overreward on pay level satisfaction. This issue needs to be resolved with a larger set of studies, perhaps those that include job satisfaction in general.

\section{Antecedents}

Perceptions of pay policies and administration (Box 4). Although various equity norms exist, the concept of basing pay on performance is ingrained within American organizations (GomezMejia \& Welbourne, 1991; R. L. Heneman, 1992). Cross-cultural research also suggests that the belief that rewards should be based on contribution (or performance) may be universally held (Hagan $\&$ Peterson, 1999). These statements provide a straightforward explanation for the relation between performance-reward contingency and pay level satisfaction. An alternative interpretation is that pay satisfaction may influence perceptions of the performance-reward contingency. Those who are satisfied with their pay may believe that their rewards are based on performance; otherwise, they may have to admit that their pay is unfair (i.e., a result of a circumstance other than the individuals' contribution to the organization). Those who are dissatisfied with their pay may blame the system (i.e., perceive that pay is not performance based) rather than admit that their performance does not warrant higher pay. Nevertheless, this result suggests that further examination of constructs within the pay administration category is warranted. H. G. Heneman and Judge's (2000) review of studies that investigated the relations among a variety of pay administration components and various dimensions of pay satisfaction can provide guidance for future research.

Perceived inputs: Non-job-related (Box 5). We see a limited role for age and marital status in future research. The small yet persistent paradox of the contented female worker and the relation between ethnicity and pay level satisfaction deserve mention. Gender was nearly unrelated to pay level satisfaction, but we found in supplemental analyses that when we controlled actual pay, women were slightly more satisfied with their pay than were men. Recent research (Davison, 2002) suggests that the most enduring explanation for this paradox is that women, for a variety of reasons (C. Lee \& Farh, 1999; Loscocco \& Spitze, 1991; J. K. Martin \& Hansen, 1985), have lower pay expectations than men. We calculated the correlation between year of study publication and the correlation between gender and pay satisfaction. This correlation was -.17 ( $p=.10 ; n=58)$, which provides evidence consistent with a view that the paradox of the contented female worker may be weakening over time (from 1974 to 2002). This is to be expected, because the gender wage gap has continued to shrink, women have become less segregated from men in the workforce, and women's income has become more important to their economic well-being. All these factors have been mentioned as either direct or indirect causes of women's pay expectations (Davison, 2002).

The differences in pay satisfaction between Whites and nonWhites was larger than the discrepancy found between men and women, yet this relation has received much less attention than that between gender and pay satisfaction. The difference between Whites and non-Whites was in the direction that we expected on the basis of pay differences between the two groups and was consistent with the literature that has examined ethnic differences in overall job satisfaction (e.g., Lankau \& Scandura, 1996; Weaver, 1998). This literature has typically found that Blacks are less satisfied than Whites with their jobs but that these differences can be explained by factors such as position (Lankau \& Scandura, 1996), pay, occupational prestige, and autonomy (Weaver, 1977). We found that pay differences between Whites and non-Whites accounted for part of the difference in pay level satisfaction. It is likely that controlling for additional factors, such as position, prestige, and autonomy, would reduce ethnic differences even further. Existing primary studies do not provide sufficient data for this analysis, so additional primary research should examine this possibility. In addition, future research should use diverse samples in which differences among specific ethnic categories are examined.

Perceived inputs: Job related (Box 5). H. G. Heneman (1985) concluded that job input variables related weakly yet negatively to pay level satisfaction. His reasoning was that job inputs would increase the level of expected pay; thus, they would indirectly lower pay satisfaction. Our results provide some support for this role for job inputs, although the highest partial correlation between job inputs and pay satisfaction when we controlled for pay was only -.08 .

\footnotetext{
${ }^{1}$ For example, Rice et al. (1989) used a 5-point scale for respondents to rate whether they wanted much more $(-2)$ or much less $(2)$ compared with their current situation. They then conducted an absolute value transformation so that wanting much more and much less were both expected to be negatively related to pay satisfaction. This is contrasted with other authors (e.g., Blau, 1994; Shapiro, 1976) who operationalized pay discrepancy as a difference score by subtracting the actual amount of pay received from the reported amount of pay that should be received. In these cases, only discrepancies in which someone makes less than he or she should were negatively related to pay satisfaction; making more than one should was associated with greater pay level satisfaction.
} 
Perceived job characteristics (Box 6). Among the core job characteristics, autonomy and task feedback were most strongly related to pay satisfaction. The relation between autonomy and pay level satisfaction is an example of a relation that is likely to be due to variation between job characteristics and actual pay. Earlier, we reported that job level was positively related to pay level satisfaction $(\rho=.23)$; thus, there may be a pattern of positive relations among job level, autonomy, pay, and pay level satisfaction (although, because of the absence of primary research studies, we could not directly examine this possibility). We posit a different explanation for the relation between task feedback and pay level satisfaction. Employees may be more accepting of their pay level if their job provides them with performance feedback, or, similarly, task-provided feedback may set realistic expectations for pay levels. Under both discrepancy and equity theories, pay levels that are close to expectations lead to high pay level satisfaction.

The partial correlations we calculated show that the relations between job characteristics and pay level satisfaction could be partially accounted for by actual pay level, at least for skill variety and job scope. These findings suggest that individuals working in enriched jobs may be paid more for their enhanced responsibility. Our results are consistent with the job redesign literature, which states that the presence of the core job dimensions contributes to satisfaction, including pay satisfaction. Campion and Berger (1990) noted that little attention has been directed to understanding how job design and compensation systems interrelate, and our analysis is based on only two studies that included measures of both job characteristics and pay. We encourage researchers working in both fields to consider these important interrelations in future research.

Perceived inputs and outcomes of referent others (Box 7). Pay comparisons are some of the strongest predictors of pay satisfaction. Our expectation that both internal and external comparisons would be more strongly related to pay level satisfaction than the more general category of comparisons was supported. In addition, our results support the basic premises of equity theory regarding the role of perceived pay of others in determining pay level satisfaction; however, the strength of these population correlations warrants further consideration. One explanation for these high population correlations is common method variance. In almost all cases, respondents were asked to compare the pay they received with the perceived inputs and outcomes of referent others and to rate their pay satisfaction using questionnaire measures collected at the same point in time. Designs that use procedural remedies such as temporal, psychological, or methodological separation of measurement (Podsakoff, MacKenzie, Lee, \& Podsakoff, 2003) to minimize common method variance should be used in future research.

Another measurement explanation for these high correlations involves the comparison questions asked of respondents. Typically, employees are asked to evaluate the pay they receive compared with the pay received by a specific group of referent others (e.g., those with the same level of experience). This approach is not consistent with Figure 1. Instead, Figure 1 depicts perceived inputs and outcomes of referent others as determinants of the perceived amount of pay that should be received rather than a direct antecedent of pay level satisfaction. As long as pay comparisons are measured via this popular method, they will dominate other predictors in empirical tests of antecedent models of pay level satisfaction. A measurement method more consistent with Figure 1 is to assess perceived inputs and outcomes of referent others without a direct comparison with the respondent's actual pay level. For example, a typical pay comparison measure asks respondents to rate their pay compared with that of a list of referents (those the same age as the respondent, other employees within the respondent's organization, etc.) using a scale of $1=$ much worse to $5=$ much better. Instead, respondents could be asked to rate their perceptions of the adequacy of outcomes referent others receive from their jobs compared with their inputs (e.g., from $1=$ highly inadequate to $5=$ highly adequate). This format allows researchers to assess inputs and outcomes of referent others independent of employees' ratings of their own pay. This separation is more consistent with the theoretical model shown in Figure 1 and is likely to reduce the inflated correlations obtained between comparisons with referent others and pay level satisfaction. Depending on the nature of the specific research questions, researchers could determine what outcomes other than pay (if any) they should assess and for which referents.

Actual pay and pay raises received (Box 8). We did not have a precise estimate of the relation between actual pay and pay level satisfaction before we conducted this meta-analysis. The mean population correlation $(\rho=.29)$ confirms that pay level is an important but not necessarily dominant determinant of pay level satisfaction. Few studies have investigated the pay raise percentage-pay level satisfaction relation. Our summary of these studies shows that pay raise percentage is only slightly related to pay level satisfaction.

\section{Correlates (Box 9)}

Our results for justice are consistent with the two-factor theory of organizational justice, which posits that distributive justice is more strongly related to personal-level evaluations than is procedural justice (Miceli \& Mulvey, 2000). Distributive justice may be more strongly related to pay satisfaction than is procedural justice, because, as a direct assessment of pay outcomes, distributive justice is a construct similar to pay level satisfaction.

General pay satisfaction was more strongly related to distributive justice than was pay level satisfaction. We expected this because most distributive justice measures address outcomes other than those concerned directly with pay level. The construct correspondence of this type of measure is closer to that of general pay satisfaction than to that of pay level satisfaction. The type of procedural justice measure moderated the relation between procedural justice and pay level satisfaction. Procedural justice and pay level satisfaction were much more strongly related when a payfocused measure of procedural justice was used than when a more general measure of procedural justice was used. As examples, Jones, Scarpello, and Bergmann (1999) used a pay-focused measure of procedural justice, the Procedural Fairness Scale (Scarpello \& Jones, 1996), which assessed the fairness of compensation procedures, such as job evaluation and pay raise determination. Alternatively, Howard (1999) used Moorman's (1991) measure, which assesses more broadly "the degree to which fair procedures are used in the organizations" and the "interpersonal behavior of the supervisor" (Moorman, 1991, p. 847). Again, the explanation here is one of construct correspondence. 
Although interest in procedural and distributive justice concepts has increased in recent decades, the justice literature has rarely been integrated with the pay satisfaction literature. Hundreds of studies have been conducted on pay level satisfaction and on distributive and procedural justice, yet only 11 studies yielded quantitative results for this analysis. Thus, basic questions concerning the causal relations among these constructs remain (e.g., H. G. Heneman \& Judge, 2000). In addition, primary studies examining the complexities of the developing justice literature (e.g., the roles of interactional and informational justice) as they relate to pay satisfaction are not represented in this meta-analysis. These are fruitful areas for additional primary research.

\section{Consequences (Box 10)}

The results for the consequences or outcomes of pay satisfaction indicate that pay satisfaction was more strongly related to attitudinal than to behavioral outcomes: The relation with turnover intentions was moderate, and the relations with behavioral outcomes were relatively weaker.

We examined two potential moderators of the weak, positive relation between pay satisfaction and performance: type of performance rating, and type of pay satisfaction measure. Objective performance measures yielded a stronger population correlation and a smaller credibility interval than the entire distribution. This stronger relation exists because, in three of the four studies, employees' pay was based on objective performance measures. In two studies, sales employees were paid on commission (Hollenbeck \& Williams, 1986; Motowidlo, 1982). In the third study, restaurant managers' pay was based on restaurant profitability (Summers \& Hendrix, 1991b). These results are consistent with the view espoused by Cherrington, Reitz, and Scott (1971) that rewards cause satisfaction and that contingent rewards cause performance. Thus, the stronger relation between pay level satisfaction and objective performance was due to the relation between pay and performance established by the reward system. The relation between pay satisfaction and performance was stronger for general pay satisfaction measures than for pay level satisfaction measures. The relation between performance and JDI-measured pay level satisfaction was stronger than the relation between performance and other pay level satisfaction measures. We examined several possible explanations for these findings (e.g., whether the performance measure was obtained from company performance appraisal ratings or conducted just for the study) but could not find compelling reasons for these differences.

The typically weak relations between pay satisfaction and its consequences might lead us to a conclusion opposite that of H. G. Heneman and Judge (2000), who stated, "Research has unequivocally shown that pay dissatisfaction can have important and undesirable impacts on numerous employee outcomes" (p. 85). We can reconcile these different viewpoints by examining the level of specificity of the research summaries presented here and by H. G. Heneman and Judge (2000). Constructs that have not been examined in multiple studies are excluded from meta-analyses. H. G. Heneman and Judge listed 11 studies that examined relations between compensation attitudes and outcomes. The majority of these studies included specific outcomes not represented in this meta-analysis - for example, lateness, prounion vote, and signing up for a job interview. Thus, we agree that future examinations of pay level satisfaction outcomes should be "behaviorally specific in terms of likely employee reactions to pay dissatisfaction" (H. G. Heneman \& Judge, 2000, p. 85) and that there is little future in examining general relations, such as that between pay level satisfaction and global job performance.

\section{Limitations and Future Research}

The limitations of meta-analysis in general apply to this study. The analysis was limited to available primary studies. For several correlates, we examined only linear, bivariate relations with pay satisfaction. We examined relations between pay level satisfaction and its correlates at the individual level. Although some pay level satisfaction research at the group or organizational level exists, Ostroff and Harrison (1999) noted that it is inappropriate to pool studies from multiple levels of analysis in a meta-analysis. As increased interest in group- and organizational-level compensation research yields more studies of pay satisfaction at higher levels of analysis, meta-analyses of those literatures should be conducted. For the perceptual correlates in our review (e.g., procedural justice, turnover intentions), the strength of the relations with pay satisfaction may be influenced by common method variance. A number of the correlates of pay level satisfaction that we examined are likely to be related. For example, it seems likely that pay policies and administration (e.g., performance reward contingency) influence the amount of actual pay and also procedural justice perceptions, and so forth. Thus, our results do not provide a comprehensive test of the model shown in Figure 1. On the basis of the results of the significance tests that indicate that moderators are likely to exist for most of the relations we examined, we urge researchers to examine the relations between these correlates and pay level satisfaction, taking other factors into account. We also recommend that researchers tailor their use of pay satisfaction measures to the specific compensation satisfaction construct in which they are interested. Our results indicate that, in some cases, use of a general pay satisfaction measure instead of a pay level satisfaction measure could influence conclusions regarding the strength of the relation between pay satisfaction and its correlates. Developments in the measurement of specific compensation satisfaction dimensions (e.g., Scarpello et al., 1988; Sturman \& Short, 2000) will allow researchers to match their measures more closely to their theoretical constructs.

Although research on the impact of personality at work has made considerable progress in recent years (Mount, Barrick, \& Ryan, 2003), only a few primary studies of personality and pay satisfaction exist (e.g., Shaw, Duffy, Jenkins, \& Gupta, 1999). We encourage researchers to include personality in their models of pay level satisfaction and to test these relations in primary research. For example, personality factors might play a role as job-related personal inputs (Box 5) in the theoretical model shown in Figure $1 .^{2}$ Employees might view traits such as conscientiousness, emotional stability, and perhaps Type A behavior as personal inputs that determine employees' perceptions of the level of pay they deserve. Such research would address Mount et al.'s (2003) call to study mediational links between personality and criteria of interest using existing constructs such as well-accepted personality traits and motivational constructs.

\footnotetext{
${ }^{2}$ We thank an anonymous reviewer for this idea.
} 


\section{Conclusions}

Pay level satisfaction has received a great deal of research attention over the past 40 years, and this meta-analysis summarizes the accumulated literature. Our results represent the best available estimates of the relations between pay level satisfaction and its primary determinants, antecedents, correlates, and consequences. In addition, we have examined these results within existing theoretical frameworks, so that our findings provide insight into how future research can make methodological and theoretical contributions to this important literature.

\section{References}

References marked with an asterisk indicate studies included in the meta-analysis.

*Abdel-Halim, A. A. (1980). Effects of higher order need strength on the job performance-job satisfaction relationship. Personnel Psychology, 33, 335-347.

Adams, J. S. (1965). Inequity in social exchange. In L. Berkowitz (Ed.), Advances in experimental social psychology (Vol. 2, pp. 267-299). New York: Academic Press.

*Adler, S., \& Golan, J. (1981). Lateness as a withdrawal behavior. Journal of Applied Psychology, 66, 544-554.

*Angle, H. L., \& Perry, J. L. (1983). Organizational commitment: Individual and organizational influences. Work and Occupations, 10, 123146.

*Baird, L. S. (1976). Relationship of performance to satisfaction in stimulating and nonstimulating jobs. Journal of Applied Psychology, 61, 721-727.

*Barling, J., Wade, B., \& Fullagar, C. (1990). Predicting employee commitment to company and union: Divergent models. Journal of Occupational Psychology, 63, 49-61.

*Bartol, K. M. (1979). Individual versus organizational predictors of job satisfaction and turnover among professionals. Journal of Vocational Behavior, 15, 55-67.

*Bartol, K. M., \& Wortman, M. D. (1976). Sex effects in leader behavior self-descriptions and job satisfaction. Journal of Psychology, 94, 177183.

*Bechtold, S. E., Sims, H. P., Jr., \& Szilagyi, A. D., Jr. (1981). Job scope relationships: A three-wave longitudinal analysis. Journal of Occupational Behavior, 2, 189-202.

*Bedeian, A. G., Ferris, G. R., \& Kacmar, K. M. (1992). Age, tenure, and job satisfaction: A tale of two perspectives. Journal of Vocational Behavior, 40, 33-48.

*Bergmann, T. J. (1981). Managers and their organizations: An interactive approach to multidimensional job satisfaction. Journal of Occupational Psychology, 54, 275-288.

*Bigoness, W. J. (1978). Correlates of faculty attitudes toward collective bargaining. Journal of Applied Psychology, 63, 228-233.

*Blau, G. J. (1985). Relationship of extrinsic, intrinsic, and demographic predictors to various types of withdrawal behaviors. Journal of Applied Psychology, 70, 442-450.

*Blau, G. J. (1994). Testing the effect of level and importance of pay referents on pay level satisfaction. Human Relations, 47, 1251-1268.

*Blau, G. J., \& Blank, W. (1989, November). An investigation of the determinants of pay satisfaction. Paper presented at the meeting of the Southern Academy of Management, New Orleans, LA.

*Brief, A. P., \& Aldag, R. J. (1975). Employee reactions to job characteristics: A constructive replication. Journal of Applied Psychology, 60, 182-186.

*Brown, K. A., \& Huber, V. L. (1992). Lowering floors and raising ceilings: A longitudinal assessment of the effects of an earnings-at-risk plan on pay satisfaction. Personnel Psychology, 45, 279-311.
*Brown, M. (2001). Unequal pay, unequal responses? Pay referents and their implications for pay level satisfaction. Journal of Management Studies, 38, 879-896.

*Buchko, A. A. (1993). The effects of employee ownership on employee attitudes: An integrated causal model and path analysis. Journal of Management Studies, 30, 633-657.

*Caldwell, D. F., \& O'Reilly, C. A., III. (1982). Task perceptions and job satisfaction: A question of causality. Journal of Applied Psychology, 67, 361-369.

Cammann, C., Fichman, M., Jenkins, G. D., \& Klesh, J. R. (1983). Assessing the attitudes and perceptions of organizational members. In S. E. Seashore, E. E. Lawler III, P. H. Mirvis, \& C. Cammann (Eds.), Assessing organizational change (pp. 71-138). New York: Wiley.

Campion, M. A., \& Berger, C. J. (1990). Conceptual integration and empirical test of job design and compensation relationships. Personnel Psychology, 43, 525-553.

*Carraher, S. M., \& Buckley, M. R. (1996). Cognitive complexity and the perceived dimensionality of pay satisfaction. Journal of Applied Psychology, 81, 102-109.

*Champoux, J. E. (1992). A multivariate analysis of curvilinear relationships among job scope, work context satisfaction, and affective outcomes. Human Relations, 45, 87-111.

*Cheloha, R. S., \& Farr, J. L. (1980). Absenteeism, job involvement, and job satisfaction in an organizational setting. Journal of Applied Psychology, 65, 467-473.

Chen, P. Y., \& Spector, P. E. (1991). Negative affectivity as the underlying cause of correlations between stressors and strains. Journal of Applied Psychology, 76, 398-407.

Cherrington, D. J., Reitz, H. J., \& Scott, W. E. (1971). Effects of contingent and noncontingent rewards on the relationship between satisfaction and task performance. Journal of Applied Psychology, 55, 531-536.

*Christiansen, N., Villanova, P., \& Mikulay, S. N. (1997). Political influence compatibility: Fitting the person to the climate. Journal of Organizational Behavior, 18, 709-730.

Churchill, G. A., Jr., Ford, N. M., \& Walker, O. C., Jr. (1974). Measuring the job satisfaction of industrial salesmen. Journal of Marketing Research, 11, 254-260.

*Churchill, G. A., Jr., \& Pecotich, A. (1982). A structural equation investigation of the pay satisfaction valence relationship among salespeople. Journal of Marketing, 46, 114-124.

*Chusmir, L. H., \& Koberg, C. S. (1990). Ethnic differences in the relationship between job satisfaction and sex-role conflict among Hispanic and non-Hispanic White individuals. Psychological Reports, 66, 567-579.

*Clark, A. E. (1993). Job satisfaction and gender: Why are women so happy at work? (Discussion Paper 415). Colchester, Essex, England: University of Essex.

*Cohen, A. (1992). Attitudinal militancy and propensity to strike among unionized engineers and x-ray technicians. Human Relations, 45, 13331366.

*Colarelli, S. M., Dean, R. A., \& Konstans, C. N. (1987). Comparative effects of personal and situational influences on job outcomes of new professionals. Journal of Applied Psychology, 72, 558-566.

Crosby, F. (1982). Relative deprivation and working women. New York: Oxford University Press.

Cross, D. (1973). The Worker Opinion Survey: A measure of shop-floor satisfaction. Occupational Psychology, 47, 193-208.

*Das, P., \& Bhadury, B. (1997). Pay satisfaction of R\&D personnel in manufacturing organizations: The role of career comparison process. Journal of High Technology Management Research, 8, 171-186.

*Davison, H. K. (2002, August). The paradox of the contented female worker: Why are women satisfied with less pay? Paper presented at the meeting of the Academy of Management, Denver, CO

*Drasgow, F., \& Miller, H. E. (1982). Psychometric and substantive issues 
in scale construction and validation. Journal of Applied Psychology, 67, $268-279$.

*Dreher, G. F. (1981). Predicting the salary satisfaction of exempt employees. Personnel Psychology, 34, 579-589.

*Dreher, G. F., \& Ash, R. A. (1990). A comparative study of mentoring among men and women in managerial, professional, and technical positions. Journal of Applied Psychology, 75, 539-546.

* Dreher, G. F., Ash, R. A., \& Bretz, R. D. (1988). Benefit coverage and employee cost: Critical factors in explaining compensation satisfaction. Personnel Psychology, 41, 237-254

*Dreher, G. F., \& Cox, T. H., Jr. (2000). Labor market mobility and cash compensation: The moderating effects of race and gender. Academy of Management Journal, 43, 890-900.

*Dulebohn, J. H., \& Martocchio, J. J. (1998). Employee perceptions of the fairness of work group incentive pay plans. Journal of Management, 24, 469-488.

*Dunham, R. B. (1977). Reactions to job characteristics: Moderating effects of the organization. Academy of Management Journal, 20, 4265.

Dunham, R. B., Smith, F. J., \& Blackburn, R. S. (1977). Validation of the Index of Organizational Reactions with the JDI, the MSQ, and Faces scales. Academy of Management Journal, 20, 420-432.

Dunlap, W. P., Cortina, J. M., Vaslow, J. B., \& Burke, M. J. (1996). Meta-analysis of experiments with matched groups or repeated measures designs. Psychological Methods, 1, 170-177.

*Dyer, L., \& Theriault, R. N. (1976). The determinants of pay satisfaction. Journal of Applied Psychology, 61, 596-604.

*Eberhardt, B. J., \& Moser, S. B. (1995). The nature and consequences of part-time work: A test of hypotheses. Journal of Applied Business Research, 11, 101-108.

Eby, L. T., Freeman, D. M., Rush, M. C., \& Lance, C. E. (1999). Motivational bases of affective organizational commitment: A partial test of an integrative theoretical model. Journal of Occupational and Organizational Psychology, 72, 463-483.

*Ellingson, J. E., Gruys, M. L., \& Sackett, P. R. (1998). Factors related to the satisfaction and performance of temporary employees. Journal of Applied Psychology, 83, 913-921.

*Elloy, D. F., Everett, J. E., \& Flynn, W. R. (1991). An examination of the correlates of job involvement. Group and Organization Studies, 16, $160-177$.

*Farh, J. L., Earley, P. C., \& Lin, S. C. (1997). Impetus for action: A cultural analysis of justice and organizational citizenship behavior in Chinese society. Administrative Science Quarterly, 42, 421-444.

*Feldman, D. C., \& Tompson, H. B. (1993). Expatriation, repatriation, and domestic geographical relocation: An empirical investigation of adjustment to new job assignments. Journal of International Business Studies, 24, 507-529.

*Ferris, G. R. (1985). Role of leadership in the employee withdrawal process: A constructive replication. Journal of Applied Psychology, 70, 777-781.

*Futrell, C., Parasuraman, A., \& Sagar, J. (1983). Sales force evaluation with expectancy theory. International Marketing Management, 12, 125129.

*Futrell, C. M., \& Varadarajan, P. R. (1985). Marketing executives' perceptions of equitable salary increases. Industrial Marketing Management, 14, 59-67.

*Garrison, K. R., \& Muchinsky, P. M. (1977). Attitudinal and biographical predictors of incidental absenteeism. Journal of Vocational Behavior, $10,221-230$

*George, J. M., \& Brief, A. P. (1990). The economic instrumentality of work: An examination of the moderating effects of financial requirements and sex on the pay-life satisfaction relationship. Journal of Vocational Behavior, 37, 357-368.
Ghiselli, E., Campbell, J. P., \& Zedeck, S. (1981). Measurement theory for the behavioral sciences. San Francisco: Freeman.

*Gomez-Mejia, L. R., \& Balkin, D. B. (1984). Faculty satisfaction with pay and other job dimensions under union and nonunion conditions. Academy of Management Journal, 27, 591-602.

Gomez-Mejia, L. R., \& Welbourne, T. (1991). Compensation strategies in a global context. Human Resource Planning, 14, 29-41.

*Goodman, P. S. (1974). An examination of referents used in the evaluation of pay. Organizational Behavior and Human Performance, 12, 170-195.

*Gordon, G. G. (1989). Relationships of personal needs to managers' perceptions of compensation. Journal of Business and Psychology, 4, $15-26$.

*Gordon, G. G., \& Rothberg, H. (1991). Some added complexities of pay satisfaction in a management population. Journal of Managerial Issues, 3, 303-318

*Graham, M. E., \& Welbourne, T. M. (1999). Gainsharing and women's and men's relative pay satisfaction. Journal of Organizational Behavior, 20, 1027-1042

*Griffin, M. A. (1997). Multilevel influences on work attitudes: Organisational and individual predictors of pay satisfaction. Australian Psychologist, 32, 190-195.

*Gupta, N. (1980). Performance-contingent rewards and satisfaction: An initial analysis. Human Relations, 33, 813-829.

*Hackman, J. R., \& Lawler, E. E., III. (1971). Employee reactions to job characteristics. Journal of Applied Psychology, 55, 259-286.

Hackman, J. R., \& Oldham, G. R. (1974). The Job Diagnostic Survey: An instrument for the diagnosis of jobs and the evaluation of job redesign projects (AD-779 828). Washington, DC: National Technical Information Service, U.S. Department of Commerce.

*Hagan, C. M., \& Peterson, M. F. N. (1999, August). Cultural specifics and universals in employee responses to pay contingencies. Paper presented at the meeting of the Academy of Management, Chicago.

*Hanisch, K. A., \& Hulin, C. L. (1990). Job attitudes and organizational withdrawal: An examination of retirement and other voluntary withdrawal behaviors. Journal of Vocational Behavior, 37, 60-78.

*Hanisch, K. A., \& Hulin, C. L. (1991). General attitudes and organizational withdrawal: An evaluation of a causal model. Journal of Vocational Behavior, 39, 110-128.

*Hemmasi, M., Graf, L. A., \& Lust, J. A. (1992). Correlates of pay and benefit satisfaction: The unique case of public university faculty. Public Personnel Management, 21, 429-443.

Heneman, H. G., III. (1985). Pay satisfaction. In M. Rowland \& J. Ferris (Eds.), Research in personnel and human resources management (Vol. 3, pp. 115-140). Greenwich, CT: JAI Press.

Heneman, H. G., III, \& Judge, T. A. (2000). Compensation attitudes: A review and recommendations for future research. In S. L. Rynes \& B Gerhart (Eds.), Compensation in organizations: Progress and prospects (pp. 61-103). San Francisco: Jossey-Bass.

Heneman, H. G., III, \& Schwab, D. P. (1979). Work and rewards theory. In D. Yoder \& H. G. Heneman Jr. (Eds.), ASPA handbook of personnel and industrial relations (Vol. 2, pp. 6.1-6.22). Washington, DC: Bureau of National Affairs.

Heneman, H. G., III, \& Schwab, D. P. (1985). Pay satisfaction: Its multidimensional nature and measurement. International Journal of Psychology, 20, 129-141.

Heneman, R. L. (1992). Merit pay: Linking pay increases to performance ratings. Reading, MA: Addison Wesley.

*Heneman, R. L., Greenberger, D. B., \& Strasser, S. (1988). The relationship between pay-for-performance perceptions and pay satisfaction. Personnel Psychology, 41, 745-759.

*Heneman, R. L., Porter, G., Greenberger, D. B., \& Strasser, S. (1997). Modeling the relationship between pay level and pay satisfaction. Journal of Business and Psychology, 12, 147-158. 
*Holdnak, B. J., Harsh, J., \& Bushardt, S. C. (1993). An examination of leadership style and its relevance to shift work in an organizational setting. Health Care Management Review, 18, 21-30.

*Hollenbeck, J. R., \& Williams, C. R. (1986). Turnover functionality versus turnover frequency: A note on work attitudes and organizational effectiveness. Journal of Applied Psychology, 71, 606-611.

*Hom, P. W., \& Hulin, C. L. (1981). A competitive test of the prediction of reenlistment by several models. Journal of Applied Psychology, 66, 23-39.

*Honeycutt, E. D., Siguaw, J. A., \& Hunt, T. G. (1995). Business ethics and job-related constructs: A cross-cultural comparison of automotive salespeople. Journal of Business Ethics, 14, 235-248.

*Howard, L. W. (1999). Validity evidence for measures of procedural/ distributive justice and pay/benefit satisfaction. Journal of Business and Psychology, 14, 135-147.

*Huber, V. L., Seybolt, P. M., \& Venemon, K. (1992). The relationship between individual inputs, perceptions, and multidimensional pay satisfaction. Journal of Applied Social Psychology, 22, 1356-1373.

*Hunt, J. W., \& Saul, P. N. (1975). The relationship of age, tenure, and job satisfaction in males and females. Academy of Management Journal, 18, 690-702.

Hunter, J. E., \& Schmidt, F. L. (1990). Methods of meta-analysis: Correcting error and bias in research findings. Newbury Park, CA: Sage.

Iaffaldano, M. T., \& Muchinsky, P. M. (1985). Job satisfaction and job performance: A meta-analysis. Psychological Bulletin, 97, 251-273.

*Igbaria, M., \& Guimaraes, T. (1993). Antecedents and consequences among information center employees. Journal of Management Information Systems, 9, 145-174.

*Inkson, J. H. K. (1978). Self-esteem as a moderator of the relationship between job performance and job satisfaction. Journal of Applied Psychology, 63, 243-247.

*Ivancevich, J. M., \& Donnelly, J. H., Jr. (1975). Relation of organizational structure to job satisfaction, anxiety-stress, and performance. Administrative Science Quarterly, 20, 272-280.

*Jacobs, R., \& Soloman, T. N. (1977). Strategies for enhancing the prediction of job performance from job satisfaction. Journal of Applied Psychology, 62, 417-421.

*Jenkins, G. D., Jr., \& Lawler, E. E., III. (1981). Impact of employee participation in pay plan development. Organizational Behavior and Human Performance, 28, 111-128.

*Jermier, J. M., Gaines, J., \& McIntosh, N. J. (1989). Reactions to physically dangerous work: A conceptual and empirical analysis. Journal of Organizational Behavior, 10, 15-33.

*Jones, F. F., Scarpello, V., \& Bergmann, T. (1999). Pay procedureswhat makes them fair? Journal of Occupational and Organizational Psychology, 72, 129-145.

*Judge, T. A. (1993). Validity of the dimensions of the Pay Satisfaction Questionnaire: Evidence of differential prediction. Personnel Psychology, 46, 331-355.

*Kacmar, K. M., \& Ferris, G. R. (1989). Theoretical and methodological considerations in the age-job satisfaction relationship. Journal of Applied Psychology, 74, 201-207.

*Katerberg, R., Jr., Hom, P. W., \& Hulin, C. L. (1979). Effects of job complexity on the reactions of part-time employees. Organizational Behavior and Human Performance, 24, 317-332.

*Keaveny, T. J., \& Inderrieden, E. J. (2000). Gender differences in pay satisfaction and pay expectations. Journal of Managerial Issues, 12, 363-379.

*Kesselman, G. A., Wood, M. T., \& Hagen, E. L. (1974). Relationships between performance and satisfaction under contingent and noncontingent reward systems. Journal of Applied Psychology, 59, 374-376.

*Khan, L. J., \& Morrow, P. C. (1991). Objective and subjective underemployment relationships to job satisfaction. Journal of Business Research, 22, 211-218.
Kinicki, A. J., McKee-Ryan, F. M., Schriesheim, C. A., \& Carson, K. P. (2002). Assessing the construct validity of the Job Descriptive Index: A review and meta-analysis. Journal of Applied Psychology, 87, 14-32.

*Klein, S. M., \& Maher, J. R. (1966). Education level and satisfaction with pay. Personnel Psychology, 19, 195-208.

*Koch, J. L., \& Rhodes, S. R. (1981). Predictors of turnover of female factory workers. Journal of Vocational Behavior, 18, 145-161.

*Koch, J. L., \& Steers, R. M. (1978). Job attachment, satisfaction, and turnover among public sector employees. Journal of Vocational Behavior, 12, 119-128.

*Konovsky, M. A., Folger, R., \& Cropanzano, R. (1987). Relative effects of procedural and distributive justice on employee attitudes. Representative Research in Social Psychology, 17, 15-24.

*Kraut, A. I. (1975). Predicting turnover of employees from measured job attitudes. Organizational Behavior and Human Performance, 13, 233243.

*Krefting, L. A. (1980). Differences in orientations toward pay increases. Industrial Relations, 19, 81-87.

*LaFollette, W. R., \& Sims, H. P., Jr. (1975). Is satisfaction redundant with organizational climate? Organizational Behavior and Human Performance, 13, 257-278.

*Landy, F. J. (1971). Motivational type and the satisfaction-performance relationship. Journal of Applied Psychology, 55, 406-413.

Lankau, M. J., \& Scandura, T. A. (1996). An examination of job attitudes of White, Black, and Hispanic nurses in a public hospital. International Journal of Public Administration, 19, 377-398.

Lawler, E. E., III. (1971). Pay and organizational effectiveness. New York: McGraw-Hill.

Lawler, E. E., III. (1981). Pay and organizational development. Reading, MA: Addison Wesley.

Lee, C., \& Farh, J. L. (1999). The effects of gender in organizational justice perception. Journal of Organizational Behavior, 20, 133-143.

*Lee, R. T., \& Martin, J. E. (1991). Internal and external referents as predictors of pay satisfaction among employees in a two-tier wage setting. Journal of Occupational Psychology, 64, 57-66.

*Levanoni, E., \& Sales, C. A. (1989). Differences in job attitudes between full-time and part-time Canadian employees. Journal of Social Psychology, 130, 231-237.

*Levinson, E. M. N. (1997). Differences in desired role functioning and job satisfaction between doctoral and nondoctoral school psychologists. Psychological Reports, 81, 513-514.

Locke, E. A., Sirota, D., \& Wolfson, A. D. (1976). An experimental case study of the successes and failures of job enrichment in the government agency. Journal of Applied Psychology, 61, 701-711.

*Lopez, E. M. (1982). A test of the self-consistency theory of the job performance-job satisfaction relationship. Academy of Management Journal, 25, 335-348.

*Loscocco, K. A., \& Spitze, G. (1991). The organizational context of women's and men's pay satisfaction. Social Science Quarterly, 72, $3-19$.

*Lum, L., Kervin, J., Clark, K., Reid, F., \& Sirola, W. (1998). Explaining nursing turnover intent: Job satisfaction, pay satisfaction, or organizational commitment? Journal of Organizational Behavior, 19, 305-320.

*Lyness, K. S., \& Thompson, D. E. N. (1997). Above the glass ceiling? A comparison of matched samples of female and male executives. Journal of Applied Psychology, 82, 359-375.

*MacEachron, A. E. (1977). Two interactive perspectives on the relationship between job level and job satisfaction. Organizational Behavior and Human Performance, 19, 226-246.

*Maimon, Z., \& Ronen, S. (1978). Measures of job facet satisfaction as predictors of the tendency to leave or the tendency to stay with an organization. Human Relations, 31, 1019-1030.

Major, B., \& Konar, E. (1984). An investigation of sex differences in pay 
expectations and their possible causes. Academy of Management Journal, 27, 777-792

*Major, B., \& Testa, M. (1989). Social comparison processes and judgments of entitlement and satisfaction. Journal of Experimental Social Psychology, 25, 101-120.

*Malka, S. (1989). Managerial behavior, participation, and effectiveness in social welfare organizations. Administration in Social Work, 13, 47-65.

* Martin, J. E., \& Lee, R. T. (1992). Pay knowledge and referents in a tiered-employment setting. Relations Industrielles, 47, 654-670.

Martin, J. K., \& Hansen, S. L. (1985). Sex, family wage earnings status and satisfaction with work. Work and Occupations, 12, 91-109.

Martinussen, M., \& Bjornstad, J. F. (1999). Meta-analysis calculations based on independent and nonindependent cases. Educational and Psychological Measurement, 59, 928-950.

*Mathieu, J. E., Hofmann, D. A., \& Farr, J. L. (1993). Job perception-job satisfaction relations: An empirical comparison of three competing theories. Organizational Behavior and Human Decision Processes, 56, 370-387.

* McClendon, J. A., \& Klaas, B. (1993). Determinants of strike-related militancy: An analysis of a university faculty strike. Industrial and Labor Relations Review, 46, 560-573.

*McElroy, J. C., Morrow, P. C., Crum, M. R., \& Dooley, F. J. (1995). Railroad employee commitment and work-related attitudes and perceptions. Transportation Journal, 34(3), 13-24.

*McElroy, J. C., Morrow, P. C., Power, M. L., \& Iqbal, Z. (1993). Commitment and insurance agents' job perceptions, attitudes and performance. Journal of Risk and Insurance, 60, 363-384.

* McFarlin, D. B., \& Frone, M. R. (1990). A two-tier wage structure in a non-union firm. Industrial Relations, 29, 145-154.

*McFarlin, D. B., \& Sweeney, P. D. (1992). Distributive and procedural justice as predictors of satisfaction with personal and organizational outcomes. Academy of Management Journal, 35, 626-637.

*McGinnis, S. K., \& Morrow, P. S. (1990). Job attitudes among full and part-time employees. Journal of Vocational Behavior, 36, 86-96.

*McNeilly, K. M., \& Russ, F. A. N. (1992). The moderating effect of sales force performance on relationships involving antecedents of turnover. Journal of Personal Selling \& Sales Management, 12, 9-20.

*Miceli, M. P., Jung, I., Near, J. P., \& Greenberger, D. B. (1991). Predictors and outcomes of reactions to pay-for-performance plans. Journal of Applied Psychology, 76, 508-521.

Miceli, M. P., \& Lane, M. C. (1991). Antecedents of pay satisfaction: A review and extension. In K. Rowland \& J. Ferris (Eds.), Research in personnel and human resources management (Vol. 9, pp. 235-309). Greenwich, CT: JAI Press.

* Miceli, M. P., \& Mulvey, P. W. (2000). Consequences of satisfaction with pay systems: Two field studies. Industrial Relations, 39, 62-87.

*Miceli, M. P., Near, J. P., \& Schwenk, C. R. (1991). Who blows the whistle and why? Industrial and Labor Relations Review, 45, 113-130.

Milkovich, G. T., \& Newman, J. M. (2005). Compensation (8th ed.). Boston: McGraw-Hill Irwin.

* Milutinovich, J. S. (1977). Black and White differences in job satisfaction, group cohesiveness, and leadership style. Human Relations, 30, 1079-1087.

*Mobley, W. H., Horner, S. O., \& Hollingsworth, A. T. (1978). An evaluation of the precursors of hospital employee turnover. Journal of Applied Psychology, 63, 408-414.

Moorman, R. H. (1991). Relationships between organizational justice and organizational citizenship behaviors: Do fairness perceptions influence employee citizenship? Journal of Applied Psychology, 76, 845-855.

*Morgeson, F. P., Campion, M. A., \& Maertz, C. P. (2001). Understanding pay satisfaction: The limits of a compensation system implementation. Journal of Business and Psychology, 16, 133-149.

*Morrow, P. C., \& Crum, M. R. (1998). The effects of perceived and objective safety risk on employee outcomes. Journal of Vocational Behavior, 53, 300-313.

*Morrow, P. C., \& McElroy, J. C. (1987). Work commitment and job satisfaction over three career stages. Journal of Vocational Behavior, 30, 330-346.

*Motowidlo, S. J. (1982). Relationship between self-rated performance and pay satisfaction among sales representatives. Journal of Applied Psychology, 67, 209-213.

*Motowidlo, S. J. (1983). Predicting sales turnover from pay satisfaction and expectation. Journal of Applied Psychology, 68, 484-489.

Mount, M. K., Barrick, M. R., \& Ryan, A. M. (2003). Research themes for the future. In M. R. Barrick \& A. M. Ryan (Eds.), Personality and work: Reconsidering the role of personality in organizations (pp. 326-344). San Francisco: Jossey-Bass.

*Mueller, C. W., Iverson, R. D., \& Jo, D. G. (1999). Distributive justice evaluations in two cultural contexts: A comparison of U. S. and South Korean teachers. Human Relations, 52, 869-893.

*Mueller, C. W., \& Wallace, J. E. (1996). Justice and the paradox of the contented female worker. Social Psychology Quarterly, 59, 338-349.

*Murray, M. A., \& Atkinson, T. N. (1981). Gender differences in correlates of job satisfaction. Canadian Journal of Behavioral Science, 13 , $44-52$.

*Nelson, M. F., Chown, D. W., \& Stone, T. H. (1999, November). Pay me more: An examination of faculty pay satisfaction. Paper presented at the meeting of the Southern Management Association, Atlanta, GA.

*Neumann, Y. N. (1980). A contingency approach for understanding equity theory and its predictions. Social Behavior and Personality, 8 $153-159$.

*Newman, J. E. (1974). Predicting absenteeism and turnover: A field comparison of Fishbein's model and traditional job attitude measures. Journal of Applied Psychology, 59, 610-615.

*Newman, J. E. (1975). Understanding the organizational structure-job attitude relationship through perceptions of the work environment. Organizational Behavior and Human Performance, 14, 371-397.

*Nicholson, N., Wall, T., \& Lischeron, J. (1977). The predictability of absence and propensity to leave from employees' job satisfaction and attitudes toward influence in decision-making. Human Relations, 30, 499-514.

*Norris, D. R., \& Niebuhr, R. E. (1983). Professionalism, organizational commitment and job satisfaction in an accounting organization. Accounting, Organizations and Society, 9, 49-59.

*Norris, D. R., \& Niebuhr, R. E. (1984). Attributional influences on the job performance-job satisfaction relationship. Academy of Management Journal, 27, 424-431.

Nunnally, J. C. (1978). Psychometric theory (2nd ed.). New York: McGraw-Hill.

*Oldham, G. R., \& Hackman, J. R. (1981). Relationships between organizational structure and employee reactions: Comparing alternative frameworks. Administrative Science Quarterly, 26, 66-83.

*Oldham, G. R., Hackman, J. R., \& Pearce, J. L. (1976). Conditions under which employees respond positively to enriched work. Journal of Ap plied Psychology, 61, 395-403.

*Oldham, G. R., Hackman, J. R., \& Stepina, L. P. (1979). Norms for the Job Diagnostic Survey. JSAS Catalog of Selected Documents in Psychology, 9(14), Ms. No. 1819.

*Oldham, G. R., Kulik, C. T., Ambrose, M. L., Stepina, L. P., \& Brand, J. F. (1986). Relations between job facet comparisons and employee reactions. Organizational Behavior and Human Decision Processes, 38, $28-47$.

*Oliver, R. L. (1977). Antecedents of salesmen's compensation perceptions: A path analysis interpretation. Journal of Applied Psychology, 62, $20-28$.

O'Reilly, C. A., III, \& Caldwell, D. F. (1979). Informational influence as 
a determinant of perceived task characteristics and job satisfaction. Journal of Applied Psychology, 64, 157-165.

*O'Reilly, C. A., III., \& Caldwell, D. F. (1985). The impact of normative social influence and cohesiveness on task perceptions and attitudes: A social information processing approach. Journal of Occupational Psychology, 58, 193-206.

*O'Reilly, C. A., III, \& Roberts, K. H. (1973). Job satisfaction among whites and nonwhites: A cross-cultural perspective. Journal of Applied Psychology, 57, 295-299.

*Orpen, C., \& Bonnici, J. (1990). The causes and consequences of pay satisfaction: A test of Lawler's model. Psychology: A Journal of Human Behavior, 27, 27-29.

Ostroff, C., \& Harrison, D. A. (1999). Meta-analysis, level of analysis, and best estimates of population correlations: Cautions for interpreting metaanalytic results in organizational behavior, Journal of Applied Psychology, 84, 260-270.

*Parasuraman, A., \& Futrell, C. M. (1983). Demographics, job satisfaction, and propensity to leave of industrial salesmen. Journal of Business Research, 11, 33-48.

*Parasuraman, S. (1982). Predicting turnover intentions and turnover behavior: A multivariate analysis. Journal of Vocational Behavior, 21, 111-121.

Pelled, L. H., Eisenhardt, K. M., \& Xin, K. R. (1999). Exploring the black box: An analysis of work group diversity, conflict, and performance. Administrative Science Quarterly, 44, 1-28.

*Penley, L. E., \& Hawkins, B. L. (1980). Organizational communication, performance, and job satisfaction as a function of ethnicity and sex. Journal of Vocational Behavior, 16, 368-384.

*Penzer, W. N. (1969). Education level and satisfaction with pay: An attempted replication. Personnel Psychology, 22, 185-199.

Podsakoff, P. M., MacKenzie, S. B., Lee, J., \& Podsakoff, N. P. (2003). Common method biases in behavioral research: A critical review of the literature and recommended remedies. Journal of Applied Psychology, 88, 879-903.

*Podsakoff, P. M., Todor, W. D., \& Skov, R. (1982). Effects of leader contingent and noncontingent reward and punishment behaviors on subordinate performance and satisfaction. Academy of Management Journal, 25, 810-821.

*Pond, S. B., III, \& Geyer, P. D. (1991). Differences in the relation between job satisfaction and perceived work alternatives among older and younger blue collar workers. Journal of Vocational Behavior, 39, 251-262.

*Rice, R. W., McFarlin, D. B., \& Bennett, D. E. (1989). Standards of comparison and job satisfaction. Journal of Applied Psychology, 74, 591-598.

*Rice, R. W., Phillips, S. M., \& McFarlin, D. B. (1990). Multiple discrepancies and pay satisfaction. Journal of Applied Psychology, 75, 386393.

*Riggio, R. E., \& Cole, E. J. (1992). Agreement between subordinate and superior ratings of supervisory performance and effects on self and subordinate job satisfaction. Journal of Occupational and Organizational Psychology, 65, 151-158.

*Roberts, J. A., \& Chonko, L. B. (1996). Pay satisfaction and sales force turnover: The impact of different facets of pay on pay satisfaction and its implications for sales force management. Journal of Managerial Issues, 8, 154-169.

*Roedel, R. R., \& Nystrom, P. C. (1988). Nursing jobs and satisfaction. Nursing Management, 19(2), 34-38.

*Rogelberg, S. G., Luong, A., Sederburg, M. E., \& Cristol, D. S. (2000). Employee attitude surveys: Examining the attitudes of noncompliant employees. Journal of Applied Psychology, 85, 284-293.

*Ronen, S. (1986). Equity perception in multiple comparisons: A field study. Human Relations, 39, 333-346.

*Rosse, J. G., \& Hulin, C. L. (1985). Adaptation to work: An analysis of employee health, withdrawal, and change. Organizational Behavior and Human Decision Processes, 36, 324-347.

Rothstein, H. R., \& McDaniel, M. A. (1989). Guidelines for conducting and reporting meta-analyses. Psychological Reports, 65, 759-770.

*Roznowski, M., \& Hulin, C. L. (1985). Influences of functional specialty and job technology on employees' perceptual and affective responses to their jobs. Organizational Behavior and Human Decision Processes, 36, 186-208.

*Sauser, W. I., \& York, M. (1978). Sex differences in job satisfaction: A reexamination. Personnel Psychology, 31, 537-547.

Scarpello, V. (1988, April). Pay satisfaction and pay fairness: Are they the same? Paper presented at the meeting of the Society for Industrial and Organizational Psychology, Dallas, TX.

Scarpello, V., Huber, V., \& Vandenberg, R. J. (1988). Compensation satisfaction: Its measurement and dimensionality. Journal of Applied Psychology, 73, 163-171.

*Scarpello, V., \& Jones, F. F. (1996). Why justice matters in compensation decision making. Journal of Organizational Behavior, 17, 285-299.

*Scholl, R. W., Cooper, E. A., \& McKenna, J. F. (1987). Referent selection in determining equity perceptions: Differential effects on behavioral and attitudinal outcomes. Personnel Psychology, 40, 113-124.

*Schwab, D. P., \& Wallace, M. J., Jr. (1974). Correlates of employee satisfaction with pay. Industrial Relations, 13, 78-89.

Scott, K. D., \& Taylor, G. S. (1985). An examination of conflicting findings on the relationship between job satisfaction and absenteeism: A meta-analysis. Academy of Management Journal, 28, 599-612.

*Seers, A., \& Graen, G. B. (1984). The dual attachment concept: A longitudinal investigation of the combination of task characteristics and leader-member exchange. Organizational Behavior and Human Performance, 33, 283-306.

Seybolt, J. W. (1976). Work satisfaction as a function of the personenvironment interaction. Organizational Behavior and Human Performance, 17, 66-75.

* Shapiro, H. J. (1976). Models of pay satisfaction: A comparative study. Psychological Reports, 39, 223-230.

*Shapiro, H. J., \& Wahba, M. A. (1978). Pay satisfaction: An empirical test of a discrepancy model. Management Science, 24, 612-622.

*Shaw, J. D., Duffy, M. K., Jenkins, G. D., \& Gupta, N. N. (1999). Positive and negative affect, signal sensitivity, and pay satisfaction. Journal of Management, 25, 189-206.

*Sims, H. P., Jr., \& Szilagyi, A. D. (1976). Job characteristic relationships: Individual and structural moderators. Organizational Behavior and $\mathrm{Hu}$ man Performance, 17, 211-230.

*Sloane, P. J., \& Williams, H. (2000). Job satisfaction, comparison earnings, and gender. Labour, 14, 473-502.

*Smart, R., \& Peterson, C. N. (1994). Stability versus transition in women's career development: A test of Levinson's theory. Journal of Vocational Behavior, 45, 241-260.

Smith, P. C., Kendall, L. M., \& Hulin, C. L. (1969). The measurement of satisfaction in work and retirement. Chicago: Rand McNally.

*Snyder, R. A., Verderber, K. S., \& Morris, J. H. (1986). Voluntary union membership of women and men: Differences in personal characteristics, perceptions and attitudes. Journal of Occupational Psychology, 59, 205-216.

Spector, P. (1997). Job satisfaction. Thousand Oaks, CA: Sage.

*Steel, B. S., \& Lovrich, N. P., Jr. (1987). Comparable worth: The problematic politicization of a public personnel issue. Public Personnel Management, 16, 23-36.

*Steffy, B. D., \& Jones, J. W. (1990). Differences between full-time and part-time employees in perceived role strain and work satisfaction. Journal of Organizational Behavior, 11, 321-329.

*Stepina, L. (1985). Position characteristics, organizational setting characteristics, and employee reactions: Test of conceptual framework. International Journal of Psychology, 20, 255-275. 
*Stepina, L. P., Hassell, B. L., Harris, J. R., \& Mayfield, C. R. (1991). A comparative test of the independent effects of interpersonal, task, and reward domains on personal and organizational outcomes. Journal of Social Behavior and Personality, 6, 93-104.

*Stone, E. F. (1975). Job scope, job satisfaction, and the Protestant ethic: A study of enlisted men in the U. S. Navy. Journal of Vocational Behavior, 7, 215-224.

*Stone, E. F. (1976). The moderating effect of work-related values on the job scope-job satisfaction relationship. Organizational Behavior and Human Performance, 15, 147-167.

*Stroh, L. K., Brett, J. M., \& Reilly, A. H. (1996). Family structure, glass ceiling, and traditional explanations for the differential rate of turnover of female and male managers. Journal of Vocational Behavior, 49, 99-118.

*Stumpf, S. A., \& Rabinowitz, S. (1981). Career stage as a moderator of performance relationships with facets of job satisfaction and role perceptions. Journal of Vocational Behavior, 18, 202-218.

*Sturman, M. C., \& Short, J. C. (2000). Lump-sum bonus satisfaction: Testing the construct validity of a new pay satisfaction dimension. Personnel Psychology, 53, 673-700.

*Summers, T. P., \& DeNisi, A. S. (1990). In search of Adam's other: Reexamination of referents used in the evaluation of pay. Human Relations, 43, 497-511.

*Summers, T. P., \& Hendrix, W. H. (1991a). Development of a turnover model that incorporates a matrix measure of valence-instrumentalityexpectancy perceptions. Journal of Business and Psychology, 6, 227245.

*Summers, T. P., \& Hendrix, W. H. (1991b). Modelling the role of pay equity perceptions: A field study. Journal of Occupational Psychology, $64,145-157$.

*Swan, J. R., Futrell, C. M., \& Todd, J. T. N. (1978). Same job-different views: Women and men in industrial sales. Journal of Marketing, 42, 92-98.

*Sweeney, P. D., \& McFarlin, D. B. (1993). Workers' evaluations of the "ends" and the "means": An examination of four models of distributive and procedural justice. Organizational Behavior and Human Decision Processes, 55, 23-40.

*Sweeney, P. D., McFarlin, D. B., \& Inderrieden, E. J. (1990). Using relative deprivation theory to explain satisfaction with income and pay level: A multistudy examination. Academy of Management Journal, 33, 423-436.

*Szilagyi, A. D., Jr., Sims, H. P., Jr., \& Keller, R. T. (1976). Role dynamics, locus of control, and employee attitudes and behavior. Academy of Management Journal, 19, 259-276.

*Tang, T. L.-P., \& Sarsfield-Baldwin, L. J. (1996). Distributive and procedural justice as related to satisfaction and commitment. S. A. M. Advanced Management Journal, 61(3), 25-31.

*Tang, T. L., \& Talpade, M. (1999). Sex differences in satisfaction with pay and co-workers: Faculty and staff at a public institution of higher education. Public Personnel Management, 28, 345-349.

*Terborg, J. R., Lee, T. W., Smith, F. J., Davis, G. A., \& Turbin, M. S. (1982). Extension of the Schmidt and Hunter validity generalization procedure to the prediction of absenteeism behavior from knowledge of job satisfaction and organizational commitment. Journal of Applied Psychology, 67, 440-449.

Tett, R. P., \& Meyer, J. P. (1993). Job satisfaction, organizational commitment, turnover intention, and turnover: Path analysis based on metaanalytic findings. Personnel Psychology, 46, 259-293.

*Tiegs, R. B., Tetrick, L. E., \& Fried, Y. (1992). Growth need strength and context satisfactions as moderators of the relations of the Job Characteristics Model. Journal of Management, 18, 575-593.

*Ting, Y. (1996). Analysis of job satisfaction of the federal white-collar work force: Findings from the Survey of Federal Employees. American Review of Public Administration, 26, 439-456.

*Ting, Y. (1997). Determinants of job satisfaction of federal government employees. Public Personnel Management, 26, 313-334.

*Tremblay, M., Roger, A., \& Toulouse, J. M. (1995). Career plateau and work attitudes: An empirical study of managers. Human Relations, 48, 221-237.

*Tremblay, M., Sire, B., \& Balkin, D. (1999). The role of organizational justice in pay and employee benefit satisfaction, and its effects on work attitudes. Group and Organization Management, 25, 269-290.

*Tremblay, M., St-Onge, S., \& Toulouse, J. (1997). Determinants of salary relevance: A field study of managers. Journal of Business and Psychology, 11, 465-484.

U.S. Bureau of Economic Analysis. (2003). National income and product account tables. Retrieved September 10, 2003, from www.bea.gov/bea/ $\mathrm{dn} /$ nipaweb

Vance, R. J., \& Biddle, T. F. (1985). Task experience and social cues: Interactive effects on attitudinal reactions. Organizational Behavior and Human Decision Processes, 35, 252-265.

*Vecchio, R. F. (1984). Models of psychological inequity. Organizational Behavior and Human Performance, 34, 266-282.

*Vest, M. J., Scott, K. D., \& Markham, S. E. (1994). Self-rated performance and pay satisfaction, merit increase satisfaction, and instrumentality beliefs in a merit pay environment. Journal of Business and Psychology, 9, 171-181.

Viswesvaran, C., Ones, D. S., \& Schmidt, F. L. (1996). Comparative analysis of the reliability of job performance ratings. Journal of Applied Psychology, 81, 557-574.

*Wanberg, C. R., Carmichael, H. D., \& Downey, R. G. (1999). Satisfaction at last job and unemployment: A new look. Journal of Organizational Behavior, 20, 121-131.

*Warr, P. B., \& Routledge, T. (1969). An opinion scale for the study of managers' job satisfaction. Occupational Psychology, 43, 95-109.

*Waters, L. K., \& Roach, D. (1971). Relationship between job attitudes and two forms of withdrawal from the work situation. Journal of Applied Psychology, 55, 92-94

*Waters, L. K., Roach, D., \& Waters, C. W. (1976). Estimates of future tenure, satisfaction, and biographical variables as predictors of termination. Personnel Psychology, 29, 57-60.

*Watson, C. J. (1981). An evaluation of some aspects of the Steers and Rhodes model of employee attendance. Journal of Applied Psychology, 66, 385-389.

Weaver, C. N. (1977). Relationships among pay, race, sex, occupational prestige, supervision, work autonomy, and job satisfaction in a national sample. Personnel Psychology, 30, 437-445.

Weaver, C. N. (1998). Black-White differences in job satisfaction: Evidence from 21 nationwide surveys. Psychological Reports, 83, 10831088 .

*Weiner, N. (1980). Determinants and behavioral consequences of pay satisfaction: A comparison of two models. Personnel Psychology, 33, 741-757.

Weiss, D. J., Dawis, R. V., England, G. W., \& Lofquist, L. H. (1967). Manual for the Minnesota Satisfaction Questionnaire. Minneapolis: Work Adjustment Project, University of Minnesota Industrial Relations Center.

Whetzel, D. A., \& McDaniel, M. A. (1988). The reliability of validity generalization data bases. Psychological Reports, 63, 131-134.

*Wiener, Y., \& Klein, K. L. (1978). The relationship between vocational interests and job satisfaction: Reconciliation of divergent results. Journal of Vocational Behavior, 13, 298-304

*Williams, A., Livy, B., Silverstone, R., \& Adams, P. (1979). Factors associated with labour turnover among ancillary staff in two London hospitals. Journal of Occupational Psychology, 52, 1-16. 
Williams, M. L. (1995). Antecedents of employee benefit level satisfaction: A test of a model. Journal of Management, 21, 1097-1128.

*Wright, B. M., \& Cordery, J. L. (1999). Production uncertainty as a contextual moderator of employee reactions to job design. Journal of Applied Psychology, 84, 456-463.

*Young, B. S., Worchel, S., \& Woehr, D. J. (1998). Organizational commitment among public service employees. Public Personnel Management, 27, 339-348.

Youngblood, S. A., DeNisi, A. S., Molleston, J. L., \& Mobley, W. H. (1984). The impact of work environment, instrumentality beliefs, per- ceived labor union image, and subjective norms on union voting intentions. Academy of Management Journal, 27, 576-590.

*Zey-Ferrell, M. (1982). Predictors of faculty intent to exit the organization: Potential turnover in a large university. Human Relations, 35, 349-372.

Received September 12, 2002 Revision received April 13, 2005 Accepted April 27, 2005

\section{Low Publication Prices for APA Members and Affiliates}

Keeping you up-to-date. All APA Fellows, Members, Associates, and Student Affiliates receive-as part of their annual dues-subscriptions to the American Psychologist and APA Monitor. High School Teacher and International Affiliates receive subscriptions to the APA Monitor, and they may subscribe to the American Psychologist at a significantly reduced rate. In addition, all Members and Student Affiliates are eligible for savings of up to $60 \%$ (plus a journal credit) on all other APA journals, as well as significant discounts on subscriptions from cooperating societies and publishers (e.g., the American Association for Counseling and Development, Academic Press, and Human Sciences Press).

Essential resources. APA members and affiliates receive special rates for purchases of APA books, including the Publication Manual of the American Psychological Association, and on dozens of new topical books each year.

Other benefits of membership. Membership in APA also provides eligibility for competitive insurance plans, continuing education programs, reduced APA convention fees, and specialty divisions.

More information. Write to American Psychological Association, Membership Services, 750 First Street, NE, Washington, DC 20002-4242. 